\title{
Magnetism for Librarians. Leone Allacci's De Magnete (1625) and its Relation to Giulio Cesare LaGalla's Disputatio de Sympathia et Antipathia (1623)
}

\author{
Christoph Sander \\ Postdoctoral Researcher, Bibliotheca Hertziana, Max Planck Institute for Art \\ History, Rome, Italy \\ c-sander@heimat.de
}

\begin{abstract}
The investigation of magnetic phenomena played a crucial role for the emergence of an experimental approach to natural philosophy in the early modern period. William Gilbert's De magnete, in particular, and Leonardo Garzoni's Due trattati, are taken to herald this development. This article brings to light a contrasting approach to magnetism, by analyzing an extensive and hitherto unknown study on the magnet by the Vatican librarian Leone Allacci, and its relation to Giulio Cesare LaGalla's Disputatio de sympathia et antipathia (1623). Allacci's De magnete (1625) which survives in a single manuscript, offers a comprehensive literature review on early modern knowledge about the magnet in a variety of disciplines, including natural history, natural philosophy, navigational science, natural magic, and medicine. Allacci incorporates Greek Byzantine authors as well into his doxographical anthology, and he commends the Paracelsian 'weapon salve,' which was condemned by most Catholics at his time.
\end{abstract}

\section{Keywords}

magnetism - Leone Allacci - Giulio Cesare LaGalla - philology - weapon salve Byzantine Studies - experimentalism - William Gilbert

Investigating magnetic phenomena certainly requires to perform experiments, without which one cannot observe magnetic attraction. Since ancient philosophers had written about the magnet and its powers, it must be assumed that 
certain magnetic experiments were conducted in antiquity. ${ }^{1}$ However, the first treatise to describe actual experiments is the medieval Epistola de magnete (1269) by Petrus Peregrinus. ${ }^{2}$ Although Peregrinus's treatise circulated widely in manuscripts, and reached print by 1520 , it did not lead to more extensive experimental research during the Middle Ages. ${ }^{3}$ Around the 158 os, the Jesuit Leonardo Garzoni composed his Due trattati della calamita, which described numerous experiments with magnets and iron needles. ${ }^{4}$ Garzoni's treatise remained in manuscript and it fell to William Gilbert the honor of publishing the first novel experimental approach in De magnete $(1600){ }^{5}$

1 I would like to thank Charlott Böhm, Sietske Fransen, Pamela Mackenzie, and the anonymous referees of the journal for their useful comments. I would like to thank András Németh for his help with identifying a passage in Tzetzes. Pamela Mackenzie, Carme Correa, and Mordechai Feingold helped with the English of this paper, for which I am also very grateful. I also thank Victoria Beyer for editing the images and designing the diagram. Finally, I wish to thank the Bibliotheca Vallicelliana (Ministero per i Beni e le Attività Culturali e per il Turismo) for granting access to their archive and the permission to reproduce the images. Funding for this research was provided by the Max Planck Research Group "Visualizing Science in Media Revolutions," led by Sietske Fransen (BH-P-19-35).

Cf. esp. Albert Radl, Der Magnetstein in der Antike: Quellen und Zusammenhänge, Boethius 19 (Wiesbaden/Stuttgart, 1988).

2 Cf. esp. Petrus Peregrinus, Opera, ed. Loris Sturlese and Ron B. Thomson, Centro di cultura medievale 5 (Pisa, 1995); Julian A. Smith, "Precursors to Peregrinus: The Early History of Magnetism and the Mariner's Compass in Europe," Journal of Medieval History 18, no. 1 (1992): 21-74; Robert Halleux, "Entre philosophie naturelle et savoir d'ingénieur: l'Epistola de magnete de Pierre de Maricourt," Archives Internationales d'Histoire des Sciences 56, no. 156-157 (2007): $3^{-17}$.

3 David Wootton, The Invention of Science: A New History of the Scientific Revolution (London, 2015), 327, even claims that the "first major field for experimental enquiry in the early modern period was the magnet." Cf. Rupert Hall, The Scientific Revolution, 1500-180o: The Formation of the Modern Scientific Attitude (London/New York, 1954), 219: "On the other hand, the inquiry into geomagnetism begun in the late sixteenth century is an example of a branch of science originating in the recent observations of practical men and followed up with profit to both theory and practice." Cf. Paolo Rossi, La nascita della scienza moderna in Europa, Fare l'Europa (Rome/Bari, 1997), 215: "Come la geologia, come il magnetismo, la chimica diventa una scienza fra il Seicento e il Settecento ed è essa stessa - a differenza della matematica, della meccanica, dell'astronomia - un prodotto della rivoluzione scientifica."

4 Cf. Leonardo Garzoni, Trattati della calamita, ed. Monica Ugaglia, Filosofia e scienza nell'età moderna 3 (Milan, 2005); Christoph Sander, "Early-Modern Magnetism: Uncovering New Textual Links between Leonardo Garzoni SJ (1543-1592), Paolo Sarpi osm (1552-1623), Giambattista Della Porta (1535-1615), and the Accademia Dei Lincei," Archivum Historicum Societatis Iesu 85, no. 2 (2016): 303-63. However, this work was not edited until 2005 and its impact thus was rather indirect, above all by inspiring other important treatises on magnetism, esp. Giambattista della Porta, Magiae naturalis librixx (Naples, 1589), 127-49; Niccolò Cabeo, Philosophia magnetica (Ferrara, 1629).

5 William Gilbert, De magnete, magneticisque corporibus, et de magno magnete tellure; physiologia noua, plurimis \& argumentis, \& experimentis demonstrata (London, 160o). References to this work are indicated by DM, followed by book and chapter and pages in brackets. There are 
Recent scholarship on Gilbert has painted a more complex picture of his 'magnetic philosophy' but it cannot be denied that his experiments impressed and inspired many readers. ${ }^{6}$ Gilbert's emphasis on experiments was, however, only part of the rhetoric underpinning his 'novel way to philosophize' (novum philosophandi genus).${ }^{7} \mathrm{He}$ also attacked what he dismissed as the 'bookish approach' of former centuries. ${ }^{8}$ Gilbert censured the 'wide ocean of books' (vastum Librorum Oceanum), full of reports about the magnet but devoid of experiments. ${ }^{9} \mathrm{He}$ wished to gather knowledge from things themselves and not from books. ${ }^{10}$

This article presents the research on magnetism by a librarian, who relied exclusively on books - seemingly without performing any experiments himself - an approach diametrically opposed to Gilbert's. The De magnete libri tres of the Vatican librarian, Leone Allacci, is an extensive manuscript study on

many studies on Gilbert. As a starting point, cf. these monographs and Ph.D. theses: Marie Luise Hoppe, "Die Abhängigkeit der Wirbeltheorie des Descartes von William Gilberts Lehre vom Magnetismus” (Inaugural-Diss., Halle (Saale)., 1914); Duane H. D. Roller, The De Magnete of William Gilbert (Amsterdam, 1959); Lois Irene Abromitis, "William Gilbert as Scientist: The Portrait of a Renaissance Amateur” (Diss., Brown University, 1977); Charles D. Kay, "William Gilbert's Renaissance Philosophy of the Magnet" (Diss., University of Pittsburgh, 1981); Stephen Pumfrey, "William Gilbert's Magnetic Philosophy, 1580-1684: The Creation and Dissolution of a Discipline" (Diss., University of London, 1987); Ingo Dietrich Evers, "W. Gilbert's Scientific Achievement: An Assessment of His Magnetic, Electrical and Cosmological Researches." (Diss., London School of Economics and Political Science, 1992); Laura Georgescu, "Devising Magnetism: Concepts and Investigative Practices” (Diss., Ghent University, 2017), http://hdl.handle.net/1854/LU-8526816.

6 Cf. esp. Pumfrey, "William Gilbert's Magnetic Philosophy," 14-65; Mary B. Hesse, "Gilbert and the Historians (I)," The British Journal for the Philosophy of Science 11, no. 41 (May 1, 1960): 1-10; Mary B. Hesse, "Gilbert and the Historians (II)," The British Journal for the Philosophy of Science 11, no. 42 (1960): 130-42; John Henry, "Animism and Empiricism: Copernican Physics and the Origins of William Gilbert's Experimental Method," Journal of the History of Ideas 62, no. 1 (2001): 99-119; Samuel Doble Gutiérrez, "Failing Myths: Magnetic Variation in Gilbert's de Magnete," in Synergia: Primer Encuentro de Jovenes Investigadores e Historia de La Ciencia, ed. Néstor Herrán (Madrid, 2007), 363-82; Marinus Anthony van der Sluijs, "A Common Miscitation of William Gilbert," Eos, Transactions American Geophysical Union 95, no. 16 (2014): 137.

$7 \quad$ DM, praef. (ijr, $\mathrm{iij}^{\mathrm{v}}$, iij $\mathrm{ij}^{\mathrm{r}}$; I, 1 (7). Cf. also Lynn Thorndike, "Newness and Craving for Novelty in Seventeenth-Century Science and Medicine," Journal of the History of Ideas 12, no. 4 (1951): 584-98; Peter Bexte, "Magnetische Diagramme: Gilberts Einübung ins indirekte Sehen," in Evidentia: Reichweiten visueller Wahrnehmung in der Frühen Neuzeit, ed. Gabriele Wimböck et al., Pluralisierung \& Autorität 9 (Berlin, 2007), 309-29. Cf. Eileen Reeves, "Old Wives' Tales and the New World System: Gilbert, Galileo, and Kepler," Configurations 7, no. 3 (1999): 301-54.

9 DM praef, $\left.(\mathrm{ij})^{\mathrm{r}}\right)$.

10 DM, praef. (ij"): "Sed vobis tantum vere Philosophantibus [... ], qui non ex libris solum, sed ex rebus ipsis scientiam quaeritis." See also Georgescu, "Devising Magnetism." 
magnetism composed in 1625 , which hitherto received no scholarly attention. ${ }^{11}$ Allacci, who came from the Greek island of Chios, is known amongst modern scholars primarily as a historian and scholar of Greek and Byzantine culture, but not as a natural philosopher. ${ }^{12}$ Yet, De magnete proves an important source for the antiquarian approach to magnetism, which is usually ascribed to Athanasius Kircher's Magnes (1641)..$^{13}$ This article will first address the issue of 'doxography' in early modern studies on the magnet, as this approach is what that characterizes Allacci's work most adequately. Following a description of the codicological condition of the manuscript-and details regarding its

11 Today the manuscript is located in Rome, Biblioteca Vallicelliana, Allacci LXXVII. In this article it is referred to simply by the indication of the folio. On Allacci, cf. Karen Hartnup, "On the Beliefs of the Greeks" Leo Allatios and Popular Orthodoxy, Medieval Mediterranean 54 (Leiden/Boston, 2004); Thomas Cerbu and Michel-Pierre Lerner, "La disgrâce de Galilée dans les Apes Urbanae: sur la fabrique du texte de Leone Allacci," Nuncius 15, no. 2 (2000): 589-610; Thomas Cerbu, "Leone Allacci, 1587-1669: The Fortunes of an Early Byzantinist” (Diss., Harvard University, 1986). In Allacci's Elogium, which probably dates from 1628 , his work is already listed as "De Magnete, et Magneticis curationibus libros tres," see the transcription from Rome, Biblioteca Vallicelliana, Allacci L 19, fol. 2v, and Cerbu, "Leone Allacci," 207. It is moreover mentioned as unprinted in Leone Allacci, De mensura temporum antiquorum \& praecipue Graecorum exercitatio (Cologne, 1645), 179; Leone Allacci, Apes Urbanae, sive De viris illvstribus, qui ab anno MDCXXX. per totum MDCXXII. Romae adfuerunt, ac typis aliquid euugarunt (Rome, 1633), 179; Leone Allacci, De templis Graecorum recentioribus, ad Joannem Morinum; De Narthece Ecclesiae veteris, ad Gasparem de Simeonibus; nec non De Graecorum hodie quorundam opinationibus, ad Paullum Zacchiam (Cologne, 1645), 239. The manuscript is thereafter first mentioned again in André Berthelot, "Rapport sur les manuscrits alchimique de Rome," Nouvelles archives des missions scientifiques et littéraires 13 (1887): 853; Paul Oskar Kristeller, Iter Italicum: A Finding List of Uncatalogued or Incompletely Catalogued Humanistic Manuscripts of the Renaissance in Italian and Other Libraries (London, 1963-1997), vol. 6, 2248. Berthelot quotes the inscription by Agostino Mariotti. Then the manuscript has been referred to in Cerbu, "Leone Allacci," 151; Hartnup, On the Beliefs of the Greeks, 294, n. 93. It is not mentioned in Emidio Martini, Catalogo di Manoscritti Greci esistenti nelle Biblioteche Italiane (Milan, 1902); Carmela Jacono, Bibliografia di Leone Allacci (1588-1669), Quaderni dell'Istituto di filologia greca della Università di Palermo 2 (Palermo, 1962). On Allacci's career as a librarian in the Vatican, see Jeanne Bignami Odier and José Ruysschaert, La Bibliothèque vaticane de Sixte IV à Pie XI: recherches sur l'histoire des collections de manuscrits, Studi e testi (Biblioteca apostolica vaticana) 272 (Vatican City, 1973), 105, 107, 109-15, 128-31, 142-43.

12 Cerbu, "Leone Allacci," abstract, calls Allacci "one of the founders of Byzantine studies." Allacci's Latin manuscript have received little attention in scholarship.

13 On Kircher's work on magnetism, see esp. Athanasius Kircher, Magnes; sive, De arte magnetica opus tripartitum (Rome, 1641); Martha Baldwin, "Athanasius Kircher and the Magnetic Philosophy" (Diss., University of Chicago, 1987); John Edward Fletcher, A Study of the Life and Works of Athanasius Kircher, "Germanus Incredibilis" with a Selection of His Unpublished Correspondence and an Annotated Translation of His Autobiography, ed. Elizabeth Fletcher, Aries Book Series 12 (Leiden/Boston, 2011), 148-52. 
composition and transmission-attention turns to the methodological and philological aspects of the work, through a comparison with a treatise by Allacci's university teacher Giulio Cesare LaGalla. This latter work, Disputatio de sympathia et antipathia, was completed in 1623, and used by Allacci for his De magnete.

\section{1 \\ Doxography}

As many historians have pointed out, Gilbert's investigation into magnetism not only depended greatly on his predecessors' ideas - particularly Peregrinusbut he also wrote the first extensive printed doxography on magnetism. ${ }^{14} \mathrm{He}$ worked on De magnete, while composing the Royal pharmacopoeia, which clearly required him to pore over hundreds of books. ${ }^{15}$ In his De magnete this preparation amounted to the mention of more than 200 names of persons and 125 works, mostly in a literature review at the beginning. Gilbert opens by stating that it "will not be useless to first present briefly the explanations of the old and the more recent authors.' 16 Of course, he does so mostly to criticize the ancient, medieval, and contemporary ideas he found in the books he surveyed. Yet, as David Wootton emphasizes, it was 'the book—or rather, in this case, the well-stocked library — that transforms the status of experiment; by crystallizing past knowledge, the library makes new knowledge possible. ${ }^{17}$ In other words, Gilbert's readings ultimately helped him to do a better job when experimenting

14 On the doxographies, cf. in particular DM I, 1; II, 3. See also W. James King, "The Natural Philosophy of William Gilbert and His Predecessors," Contributions from the Museum of History and Technology Series Bulletin 218 (1959): 121-39. Lists of Gilbert's references can be found in Silvanus P. Thompson, Notes on the De Magnete of Dr. William Gilbert (London, 1901). On Gilbert's sources, see also Paul Fleury Mottelay, Bibliographical History of Electricity \& Magnetism, Chronologically Arranged. Researches into the Domain of the Early Sciences, Especially from the Period of the Revival of Scholasticism, with Biographical and Other Accounts of the Most Distinguished Natural Philosophers throughout the Middle Ages (London, 1922), 501-41. Cf. also Abromitis, "William Gilbert," 84-105, 137-48. Wootton, The Invention of Science, 330, also states: "[Gilbert] had either bought books in vast quantities or had had access to a remarkable library, for On the Magnet begins with the first systematic literature review."

15 On his medical sources, see Abromitis, "William Gilbert," 89.

16 See DM II, 3 (6o): "Iam vero non inutile erit etiam primum aliorum rationes, tam veterum quam recentiorum breviter producere." In one copy of Gilbert (160o) held at the Biblioteca Nazionale Centrale di Firenze (shelfmark MAG L.5.1.168) in this doxographical chapter all names mentioned in the text were also written in the margin by an unknown reader, who apparently was particularly interested in Gilbert's name-dropping.

Wootton, The Invention of Science, 330. 
and promoting his method rhetorically against a backdrop of erudite but allegedly inconclusive and empirically mistaken works of earlier times.

This view on Gilbert is certainly justified. Numerous authors followed similar strategies, comparing their work to previous research on the same topic in order to underline their own contributions. Already Alexander of Aphrodisias presented the pre-Socratic ideas about the cause of magnetic attraction before adding his own critique. ${ }^{18}$ Garzoni and many other sixteenth-century authors followed suit, so that authors of the next century confessed to being illequipped to cover all available theories. Benedetto Ceruti and Andrea Chiocco, for example, stated in 1622 that there were as many opinions on the cause of magnetic phenomena as there were authors who commented on it (quot homines, tot esse sententias). ${ }^{19}$ Robert Fludd (1638) titled his doxography, which he copied almost entirely from Gilbert, as a 'chaos of opinions' (Chaos opinionum), and described it as an odyssey across the 'seas of opinions' (incerta et tempestuosa maria opinionum), in which philosophers searched in vain for the rocky island on which the nature of the magnet is to be found. ${ }^{20}$ Johann $\mathrm{Ru}-$ dolph Camerarius (1627) even proceeded to collate whole sections from contemporary works and to identify their sources with endnotes. ${ }^{21}$

Arguably, it is primarily this 'information overload' that Leone Allacci's $D e$ magnete seeks to address. ${ }^{22}$ Already in the 1620 s the discussions about the cause of magnetic phenomena had reached a point where it seemed nothing certain could be said about it. Along these lines, Allacci also asked what could be said for certain about this issue (Quid igitur hac in re certistatuendum est?). ${ }^{23}$ Quite differently from Garzoni and Gilbert, Allacci is not concerned with simply using different, and supposedly mistaken, opinions to sharpen his own ideas or to prepare the ground for experiments testing the hypotheses of

18 Alexander von Aphrodisias, Scripta minora Quaestiones. De Fato. De Mixtione, ed. Ivo Bruns, Commentaria in Aristotelem graeca, Supplementum Aristotelicum, 2.2 (Berlin, 1892), 72-74; Radl, Der Magnetstein in der Antike, 78-85.

19 Benedetto Ceruti and Andrea Chiocco, Musaeum Franc. Calceolarii iun. Veronensis: in quo multa ad naturalem, moralemque philosophiam spectantia, non pauca ad rem medicam pertinentia erudite proponuntur, \& explicantur; non sine magna rerum exoticarum supellectile (Verona, 1622), 264. Cf. also Johann Sperling, Institutiones physicae, 2nd ed. (Wittenberg, 1649), 1077: "De causa alii sentiunt aliter."

20 See Robert Fludd, Philosophia Moysaica (Gouda, 1638), 96v-99r: "Author prooemium ad istum suum discursum Magneticum in hoc capite facit, et tum postea ad Chaos opinionem de attractiva corporum magneticorum origine et virtute procedit."

21 See Johann Rudolph Camerarius, Sylloges Memorabilium Medicinae et Mirabilium Naturae Arcanorum, vol. 8 (Strasbourg, 1627), 59-75.

22 On the issue of "information overload," see esp. Ann Blair, Too Much to Know: Managing Scholarly Information before the Modern Age (New Haven, 2010).

23 See fol. $26 \mathrm{v}$. 
others. As the following sections will show, Allacci made critical remarks about some theories but was very reluctant to present his own; nor did he describe any original experiments. His approach can be further distinguished from existing doxographies on magnetism in at least three aspects: unlike the majority of his predecessors and contemporaries, he included many and long literal quotations; he quoted Greek sources in the original, especially from Byzantine authors (hardly anyone did so before him); he copied images from printed books, which other authors in the field of magnetism did neither by acknowledging their source nor as doxographical strategy.

The folio volume of the manuscript in the Biblioteca Vallicelliana in Rome contains Allacci's work De magnete in an autograph and in an apograph.$^{24}$ The autograph contains three 'books' totaling more than 200 folio pages (fols. 1r114r), but without a foreword, a dedication, or a conclusion. ${ }^{25}$ Allacci wrote on half pages, in columns; he wrote only on the left hand side in order to preserve readability on the verso page, because the ink tends to shine through the thin paper. Moreover, he chose this layout in order to add mostly small, but also extensive, additions in many places. ${ }^{26}$ Sometimes even separate snippets with Allacci's additions were inserted. Allacci himself drew some images from printed works into his manuscript, which will be discussed later. ${ }^{27}$

The manuscript is dated 25 October $1625 .{ }^{28}$ Three years earlier, Pope Gregory XV commissioned Allacci to transfer the holdings of the Bibliotheca Palatina from Heidelberg to Rome. ${ }^{29}$ Allacci refers in De magnete to holdings in the Palatina and in the Vatican, the latter in which he worked since 1618 , and was appointed 'scriptor' for Greek in $1619 .{ }^{30}$ In addition, Allacci refers to books published in 1623 and 1624 , but not later. ${ }^{31} \mathrm{He}$ even states that he was in Rome when

24 Photographs of some autographs by Allacci are to be found in Cerbu, "Leone Allacci," 310-13; Cerbu and Lerner, "La disgrâce de Galilée."

25 The page dimensions are $267 \mathrm{~mm} \times 200 \mathrm{~mm}$.

26 See n. 70.

27 See n. 88.

28 The dating reads "1625. 25 Octobris" (fol. 1 r).

29 Cf. the good summary in Hartnup, On the Beliefs of the Greeks, 53-84.

3o See $n .72$ and 73 .

31 See, e.g., fols. 53v, 63r, 177v, 302r for reference to Marin Mersenne, Quaestiones celeberrimae in Genesim: cum accurata textus explicatione (Paris, 1623); Robert Hues and Jodocus Hondius, Tractatus de globis, coelesti et terrestri eorumque vsu (Amsterdam, 1624); Willebrord Snellius, Tiphys batavus, sive, Histiodromice, de navium cursibus, et re navali (Leiden, 
De magnete was written. ${ }^{32}$ Thus, the date and place of the manuscript seem to be well secured.

Some aspects of Allacci's biography will shed light on the characteristics and goals of his work. Allacci completed his studies of philosophy and theology in Rome in 1610, occasionally returning to Chios, and in 1616, again in Rome, he began to study medicine. He studied under the famous physician Giulio Cesare LaGalla. ${ }^{33}$ Upon completing his studies, he practiced medicine for a short time, but then resumed working in libraries. ${ }^{34}$ Allacci's interest in medicine is rather indirectly evidenced in his works: what particularly interested him were 'secrets of nature.' ${ }^{35}$ However, his philosophical, theological and medical background is clearly expressed in De magnete - not only in the selection of sources, but in his evident knowledge of relevant philosophical and theological discourses. Moreover, the entire third book of De magnete is dedicated to the medical use of the magnet and magnetism, especially regarding the so-called weapon salve, which shall be discussed below. ${ }^{36}$

Of particular importance is Allacci's relation to LaGalla, who died in 1624. In 1622, while at Heidelberg, Allacci edited a short cosmological disputation by his former teacher, in which he referred to some of LaGalla's extant unedited writings (libri edendi), including a treatise called 'De sympathia et antipathia rerum. ${ }^{37}$ Allacci also wrote a biography of LaGalla, printed in 1644, and mentions his unpublished works, listing 'De sympathia et antipathia rerum' again. ${ }^{38}$ In De magnete, Allacci not only mentions LaGalla several times, but also refers to this unedited writing, the Disputatio de sympathia et antipathia. ${ }^{39}$ According

1624). In Allacci, Apes Urbanae, 199, the work by Cabeo, Philosophia magnetica, is already mentioned, but not in Allacci's De magnete.

32 See fol. 336 r.

33 Cf. Italo Gallo, "Il filosofo padulese Giulio Cesare Lagalla tra Aristotele e Galilei," Studi umanistici piceni 7 (1987): 111-25; Italo Gallo, "Ancora su Giulio Cesare Lagalla: medicina e tecnica della dissimulazione," Studi umanistici piceni 8 (1988): 167-74. On Allacci and LaGalla, see Cerbu, "Leone Allacci," 122.

34 Cf. Cerbu, "Leone Allacci," 39.

35 See Hartnup, On the Beliefs of the Greeks, 293-94.

36 See n. 100.

37 Cf. Giulio Cesare LaGalla, De Coelo Animato Disputatio, ed. Leone Allacci (Heidelberg, 1622), 44. In Allacci, Vita, 10, it is clearly stated that Allacci edited this work while in Heidelberg working at the Palatina library. Cf. also a letter of LaGalla himself in Gallo, "Ancora su Giulio Cesare Lagalla," 170.

38 Cf. Leone Allacci, Julii Caesaris Lagallae, philosophi romani vita (Paris, 1644). Cf. also n. 127.

39 See fols. 307r, 314v, 344r. The manuscript of De sympathia is also located in Rome, Biblioteca Vallicelliana, Allacci Xxx, no. 4: "disputatio de sympathia et antipathia." The manuscript of Allacci's Vita of LaGalla is also contained in Allacci Xxx. On the last folio (fol. 97r, in Allacci Xxx), De sympathia it is dated "Romae in fasto Sanctissimae Magdalenae Anno 
to the manuscript copy of this disputation, LaGalla had finished this treatise in Rome in 1623 . Some time afterwards, it was copied together with two other short disputations by LaGalla, along with Allacci's biography. Today this codex contains the only known manuscript copies of the works and it remains in the Vallicelliana library within the Allacci collection. ${ }^{40}$ As will be shown in more detail in the next section, Allacci's De magnete relies heavily on LaGalla's De sympathia; thus this disputation deserves some attention as well. While the professor of medicine appears as a critical natural philosopher and physician, Allacci's own (and more original) approach is characterized by a literary and scholarly treatment of the topic of magnetism-a skill that most clearly corresponds to his profession as librarian.

It is not entirely clear what happened to Allacci's manuscript of De magnete during his lifetime; after his death in 1669, he left behind a large number of manuscripts, which were collected in the eighteenth century by Raphaele Vernazza, who was himself Greek 'scriptor' of the Vatican Library from $1758 .{ }^{41}$ Vernazza copied some of Allacci's manuscripts, including De magnete. This apograph is much longer (about 6oo pages, fols. $115 \mathrm{r}-418 \mathrm{r}$ ), much easier to read, and Vernazza had already implemented all of Allacci's insertions. He copied the first and third book in full, but only the major illustrations from the second book. In addition, many of the Greek quotations in De magnete were apparently left blank in the apograph and added later, perhaps by another hand. After his death in 1780, Vernazza left his 'Allacciana' to his friend Agostino Mariotti, who probably created the title page that reads 'Leonis Alatii de Magnete libri tres. Autographum integrum cum Apocrapho Manco. Ineditum.'42 It appears that since then nobody has been interested in the content of the volume at the Vallicelliana, containing autograph and apograph.

1623. Sede vacante." So, it was probably completed on 22 July 1623 , but certainly before Maffeo Barberini was elected pope Urban viII on 6 August. The fact that the work is mentioned already in 1622 (as unedited, in Allacci's edition of LaGalla's De coelo animato) is however puzzling. Maybe it had not been completed by this time. The manuscript copy in Allacci Xxx is divided in (and arguably copied from) two quinternions (Quinternio), with a third one beginning after the obvious end of the text (fol. 97r) that is labelled but without any content. Dating the work (at least the second quaternion) before 1621 is however impossible, as LaGalla refers to a work by van Helmont of this year (fol. 86r) and to some personal experiences in this year in Rome (fol. 84v).

All four works in Allacci Xxx seem to be written by the same scribe, but in different stages and especially the Vita is hardly readable as the inks shines through in every page. It cannot be ruled out that all are copied by Allacci himself. It was, however, probably not copied by Vernazza (cf. $\mathrm{n} 41$ ). A paleographic analysis awaits to be done in future research. Cf. Cerbu, "Leone Allacci," 20, n. 11; Bignami Odier and Ruysschaert, La Bibliothèque, 168, 179, 182, 209 . 
Allacci explains the structure of his three-part De magnete only at the beginning of the third book: the first book deals with the nature and the attraction of the magnet, the second with the directional force to the pole and magnetic declination, the third with the use of the magnet in medicine, including the weapon salve. ${ }^{43}$ The first book is the longest, but the third book is the part in which Allacci often reveals his own opinions. Therefore, these two parts deserve special attention. The following synopsis presupposes knowledge about the early modern research on magnetism, which cannot be developed in this article. ${ }^{44}$

Allacci's work is characterized, above all, by the numerous quotations from Greek and Latin sources. He often copies not just lines, but whole pages or sections from other works. De magnete can be considered an anthology of ancient, medieval, and contemporary knowledge. Allacci's own views and arguments on the magnet often take a back seat. Experiments conducted by Allacci himself are not described at all. Hence, although the scope of his doxography is unpreceded, at many points Allacci owes much to his teacher LaGalla, which is why his De sympathia - the manuscript treatise of which Allacci knew well—deserves a short introduction; it will be compared to De magnete often in the course of the discussion.

LaGalla's De sympathia is a short 'disputation'-although it does not follow the structure of a typical university disputation - of sixteen chapters, divided into two quinternions (Quinternio), with a total of some 100 pages (fols. $44 \mathrm{r}-$ 97r, in Allacci XXX). ${ }^{45}$ As already mentioned, its composition began before 1622 and was completed in July 1623 in Rome. ${ }^{46}$ Owing to the large size of the handwriting, however, it is in fact five times shorter than De magnete. The work deals with the concept of 'sympathy and antipathy' its definition, and its explanations, especially as a critique of Gerolamo Fracastoro, Geralomo Cardano,

43 See fol. 256r: "Naturam, et vim attractricem Magnetis explicavi libro primo. Directionem ad polum, et deflexionem libro secundo: quae humano generi commoda inde oriantur utrisque; tertio hoc eius usum in Medicinis, Physicis, et Chymicis, nec non unguenti Magneti, quod vocant Armarium, multiplicem illum quidem ac varium ad compendium conferam."

44 Apart from further reading suggested in the footnotes, my monograph explains and analyses in detail the topics and theories, and may be consulted for further clarification. See Christoph Sander, Magnes. Der Magnetstein und der Magnetismus in den Wissenschaften der Frühen Neuzeit, Mittellateinische Studien und Texte 53 (Leiden/Boston, 2020). This article draws on research presented in this monograph, especially on chapter 10.1.4.5.

45 See. n. 39.

$46 \quad$ See. n. 39 . 
and Julius Caesar Scaliger. ${ }^{47}$ The attraction of the magnet is discussed only as one of many examples in nature of 'symapthy and antipathy.'48 The last five chapters deal exclusively with the weapon salve (fols. 84r-97r, in Allacci xxx). Indeed, it is this account that seems to have had the biggest impact on Allacci, although further links exist between De sympathia and De magnete, as will be outlined in the following synopsis. ${ }^{49}$

The first of the twelve chapters of the first book of Allacci's De magnete introduces the magnet as a 'miracle of nature.' To this end, Allacci relies on a large number of sources that emphasize how marvelous and special are the powers of the magnet. ${ }^{50}$ The second chapter is dedicated to the naming of the magnet and the etymology of these expressions, and is thus bound to natural history and lapidaries traditions. ${ }^{51}$ This approach also dominates the following three chapters, which deal with the geological sources of magnets, and what were understood to be different types of magnets, such as the 'theamedes' or the 'androdamas. 52 Also discussed is the quasi-magnetic attraction of other

47 Cf. esp. Gerolamo Fracastoro, De sympathia et antipathia rerum liber unus, ed. Concetta Pennuto, Studi e testi del rinascimento europeo 31 (Rome, 2008). See also Guido Giglioni, "Scaliger versus Cardano versus Scaliger," in Forms of Conflict and Rivalries in Renaissance Europe, ed. David A. Lines, Jill Kraye, and Marc Laureys (Göttingen, 2015), 109-30; Ulrich Gottfried Leinsle, "Wie treibt man Cardano mit Scaliger aus? Die (Nicht-)Rezeption Cardanos an der Jesuitenuniversität Dillingen," in Spätrenaissance-Philosophie in Deutschland 1570-1650: Entwürfe zwischen Humanismus und Konfessionalisierung, okkulten Traditionen und Schulmetaphysik, ed. Martin Muslow, Frühe Neuzeit 124 (Tübingen, 2009), 253-77. See also n. 53 .

48 The magnet is discussed in chapter seven (fol. 73r, in Allacci xxx: "Exemplum Sympathiae atque Anipathiae Magnetis proponitur, et examinatur"). The magnet is also mentioned

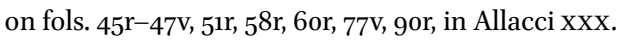

49 In the following outline of Allacci's De magnete these links will mainly be indicated in footnotes.

50 Cf., e.g., Lorraine Daston and Katharine Park, Wonders and the Order of Nature, 1150-1750 (New York, 1998), 21, 39, 111-12, 122; Bert Hansen, Nicole Oresme and The Marvels of Nature: A Study of His De Causis Mirabilium with Critical Edition, Translation, and Commentary, Studies and Texts (Pontifical Institute of Mediaeval Studies) 68 (Toronto, 1985), 67, 385; Concetta Pennuto, Simpatia, fantasia e contagio: Il pensiero medico e il pensiero filosofico di Girolamo Fracastoro (Rome, 2008), 25-47; Johannes M. Machielsen, Martin Delrio: Scholarship and Demonology in the Counter-Reformation, A British Academy Postdoctoral Fellowship Monograph (Oxford, 2015), 241; Keagan Brewer, Wonder and Skepticism in the Middle Ages, Routledge Research in Medieval Studies 8 (London/New York, 2016), 33, 38.

51 On lapidaries, see, as a starting point, Lynn Thorndike, $A$ History of Magic and Experimental Science (New York, 1923-1958), vol. 6, 298-324; Wendell E. Wilson, "The Mineralogical Record," Annotated Bio-Bibliography of Mineralogy and Crystallography 1469-1919 by Curtis P. Schuh (1959-2007), 2013, http://www.minrec.org/library.asp.

$5^{2}$ Cf. Christoph Sander, "Magnetismus und Theamedismus. Eine Fallstudie zur Kenntnis der magnetischen Abstoßung in der Naturkunde der Frühen Neuzeit," Sudhoffs Archiv 101, no. $1(2017): 42-72$. 
substances, such as 'naphtha,' 'amphitane,' 'pantarbe,' or 'chrysocolla,' as well as the hostility of the magnet to garlic and diamond..$^{53}$ Allacci is less concerned here with a critical revision of his predecessors than with the collection of textual sources.

Chapters six to eight are devoted to the cause of magnetic attraction from a natural-philosophical perspective. Nearly all theories available until 1625 are discussed. ${ }^{54}$ Allacci is often critical in these sections, but keeps a low profile regarding his own opinions, and seemingly agrees with the authors who emphasize the inexplicability of the phenomenon. ${ }^{55} \mathrm{~A}$ similar tendency is also present in LaGalla's De sympathia, which deals with Fracastoro's theory of 'sympathy' and ancient atomistic accounts of magnetic attraction. ${ }^{56}$ The ninth chapter of De magnete is devoted to magnetic analogies in numerous fields, including theology, medicine, meteorology, and cosmology, all of which are

53 Most of this has its origin in Pliny's Natural History and shall not be discussed here. Cf. only Radl, Der Magnetstein in der Antike, 54. For early modern discussions, cf., e.g., Julius Caesar Scaliger, Exotericarum exercitationum lib. XV. de subtilitate, ad Hieronymum Cardanum (Frankfurt, 1582), 270; Georg Agricola, Opera (Basel, 1546), 286. On the antipathy of the magnet with garlic and diamonds, cf. also Friedrich Ohly, Diamant und Bocksblut: zur Traditions- und Auslegungsgeschichte eines Naturvorgangs von der Antike bis in die Moderne (Berlin, 1976); W. E. May, "Garlic and the Magnetic Compass," The Mariner's Mirror 65, no. 3 (1979): 231-34; Daryn Lehoux, "Tropes, Facts, and Empiricism," Perspectives on Science 11 (2003): 326-345; Sander, Christoph. "Magnets and Garlic: An Enduring Antipathy in Early-Modern Science." Intellectual History Review, forthcoming 2020. The antipathy between garlic and magnets is refuted by LaGalla based on Giambattista della Porta's trial, cf. fol. 51r, in Allacci Xxx. On magnets and diamonds in LaGalla, see fols. 47r, 75v, in Allacci Xxx.

54 For an overview, see Jean Daujat, Origines et formation de la théorie des phénomènes électriques et magnétiques, Exposés d'histoire et philosophie des sciences 10-12 (Paris, 1945); Silvia Parigi, Spiriti, effluvi, attrazioni: la fisica "curiosa" dal Rinascimento al secolo dei lumi, Momenti e problemi della storia del pensiero 5 (Naples, 2011), 23-168.

55 Cf., e.g., Aurelius Augustinus, De civitate dei libriXI-XXII, ed. B. Dombart and A. Kalb, Corpus Christianorum, Series Latina 48 (Turnholt, 1955), 764; Giovanni Costeo, De universali stirpium natura, libri duo (Turin, 1578), 16; Amédée Meigret, Questiones in libros de c[o]elo [et] $m u[n]$ do Aristotelis (Paris, 1514), 37r; Filippo Beroaldo and Sextus Propertius, Al. Tibvlli Elegiaru $[m]$ libri quatuor: vna cum Val. Catulli Epigrammatis: nec non [et] Sex. Propertij libri quatuor Elegiaci (Venice, 1520), 166v; Pompilio Azzali, De omnibus rebus naturalibus quae continentur in mundo videlicet. Coelestibus et terrestribus necnon mathematicis. Et de angelis motoribus quae coelorum (Venice, 1544), 117v; Bartolomeo Crescentio Romano, Nautica Mediterranea (Rome, 1602), 208; Pietro Maria Castiglione, Admiranda naturalia ad renum calculos curandos (Milan, 1622), 119; Christoph Entzelt, De re metallica: lib. III (Frankfurt, 1551), 176; Marbod of Rennes and Georg Pictorius, De lapidibus pretiosis Enchiridion: cum scholiis Pictorii Villingensis: eiusdem Pictorii de lapide molari carmen (Freiburg (Brsg.), 1531), 43r. In some places, however, Allacci seems to assume that the magnet works by emitting an immaterial substance. See $\mathrm{n} .93$ and 112. Cf. fols. 57v-6or, 62r-65v, 73r-74v, in Allacci Xxx. 
absent in LaGalla's treatise. ${ }^{57}$ Allacci even sketches Johannes Kepler's 'magnetic astronomy. ${ }^{18}$ The tenth chapter deals mainly with the use of the magnet in the context of 'magia naturalis,' for example, in discussions about a magnetic 'telegraph. ${ }^{59}$ Here, he also mentions techniques to influence the magnet's power, for example, by percussion, heat, or iron caps. ${ }^{60}$ The eleventh chapter takes a critical look at the magical uses of the magnet-for example, as a loyalty test or in love spells. ${ }^{61}$ For Allacci, these applications of the magnet are

57 Much research needs to be done on this. Cf., as a starting point, Franz Posset, "The Heavenly Magnet: On the Attractiveness of God in Western Christian Spirituality," The American Benedictine Review 46, no. 1 (1995): 24-44; Fritz Krafft, "Vom Segen und Fluch einer Analogiesympathia is a short 'disputation Johannes Keplers kosmischer Magnetismus," in Analogien in Naturwissenschaften Medizin und Technik, ed. Klaus Hentschel, Acta historica Leopoldina 56 (Halle (Saale), 2010), 171-93; Michael Rogers McVaugh, "Losing Ground. The Disappearance of Attraction from the Kidneys," in Blood, Sweat and Tears: The Changing Concepts of Physiology from Antiquity into Early Modern Europe, ed. Claus Zittel, Manfred Horstmanshoff, and Helen King, Intersections 25 (Leiden/Boston, 2012), 103-37; Angus Fletcher, "Living Magnets, Paracelsian Corpses, and the Psychology of Grace in Donne's Religious Verse," English Literary History 72, no. 1 (2005): 1-22.; Christoph Sander, "Nutrition and Magnetism. An Ancient Idea Fleshed out in Early Modern Natural Philosophy, Medicine and Alchemy," in Nutrition and Nutritive Soul in Aristotle and Aristotelianism, ed. Roberto Lo Presti and Georgia-Maria Korobili, Topics in Ancient Philosophy (Berlin, forthcoming 2020).

58 See Siegmund Günther, "Johannes Kepler und der tellurisch-kosmische Magnetismus," Geographische Abhandlungen 3, no. 2 (1888): 1-71; Daujat, Origines et formation, 165-79; Heinz Balmer, Beiträge zur Geschichte der Erkenntnis des Erdmagnetismus, Veröffentlichungen der Schweizerischen Gesellschaft für Geschichte der Medizin und der Naturwissenschaften 20 (Aarau, 1956), 403-21; Alberto Elena, "On the Different Kinds of Attractive Forces in Kepler," Archives Internationales d"Histoire des Sciences 33 (1983): 22-29; Baldwin, "Athanasius Kircher," 197-206.

59 See Timoteo Bertelli, "Di un supposto sistema telegrafico magnetico: indicato da alcuni autori dei secoli XVI e XVII," Bullettino di Bibliografia e di storia delle scienze matematiche e fisiche 1 (1868): 186-96; George August Vorsterman van Oyen, "La première idée du télégraphe magnétique," Bullettino di Bibliografia e di storia delle scienze matematiche e fisiche 1 (1868): 100. Cf. also Balmer, Erdmagnetismus, 549-62.

6o See Allan A. Mills, "The Lodestone: History, Physics, and Formation," Annals of Science 61, no. 3 (July 2004): 273-319; Allan A. Mills, "William Gilbert and 'Magnetization by Percussion," Notes and Records of the Royal Society 65, no. 4 (2011): 411-16.

61 This lore originates in ancient magic but was much repeated in later centuries. Cf. Alexander Neckam, De naturis rerum libri duo, ed. Thomas Wright, Rerum Britannicarum medii aevi scriptores 34 (London, 1863), 178; Thomas von Cantimpré, Liber de natura rerum, ed. Helmut Boese, vol. 1 (Berlin, 1973), 365; Albertus Magnus (Ps.), Le "Liber de virtutibus herbarum, lapidum et animalium" (Liber aggregationis) un texte à succès attribué à Albert le Grand, ed. Isabelle Draelants, Micrologus' Library 22 (Florence, 2007), 291; Pierre Bersuire, Reductorii moralis libri quatuordecim: perfectam officiorum atque morum rationem ac penè totam naturae diligenter complectentes historiam (Venice, 1583), 465, 482. 
'superstitious' (superstitiosus), often demonic and heterodox in nature, and therefore mostly to be condemned. The last chapter discusses briefly the use of the 'white magnet' in medicine. ${ }^{62}$

A complete list of authors mentioned by Allacci provides further information on his intellectual profile. He quotes only three medieval Arabic authors, and only fourteen authors of the Latin Middle Ages. ${ }^{63}$ In contrast, he names 58 ancient authors-a clearly humanist gesture. ${ }^{64}$ Also significant is that Allacci introduces eleven Byzantine authors into the early modern discourse about magnetism, often for the first time. ${ }^{65}$ The authors of the European Renaissance

62 Cf. Gerolamo Cardano, De subtilitate libri XXI (Basel, 1560), 499; Gerolamo Cardano, De subtilitate libri XXI (Paris, 1550), 16or. Cardano's story about the treatment with the "white magnet" was widely discussed. Cf., e.g., Pierre Boaistuau, Histoires prodigieuses, extraictes de plusieurs fameux autheurs grecz et latins, sacrez et prophanes (Paris, 1560), 5or; Antoine Mizauld, De arcanis naturae, libelli quatuor (Paris, 1558), 39r; Gerolamo Zanchi, De Operibvs Dei Intra Spacivm Sex Diervm Creatis: Opvs Tres In Partes Distinctvm (Neustadt an der Haardt, 1591), 351; Johann Jacob Wecker, De secretis libri XVII. Ex variis authoribus collecti (Basel, 1642), 149; Athanasius Kircher and Johann Jacob Schweigkhard von Freihausen, Ars magnesia: hoc est disquisitio bipartita empeirica seu experimentalis, physicomathematica de natura, viribus et prodigiosis effectibus magnetis (Würzburg, 1631), 58.

63 The Arab writers are: Averroes, Avicenna, Haly Abenragel. The authors of the Latin Middle Ages are: Albertus Magnus, Arnaldus de Villanova, Bartholomaeus Anglicus, Henry of Ghent, Hugh of Saint-Cher, Johannes Capreolous, Johannes de Indagine, Macer floridus (held for the ancient poet Aemilius Macer), Pelbart of Timeswar, Petrus Damiani, Petrus Peregrinus, Roger Bacon, Thomas Aquinas, Wilhelm of Auvergne.

64 The authors are: Achilles Tatius, Alexander of Aphrodisias, Ambrose of Milan, Antigonos of Karystos, Apollonius Dyscolus, Apollonius of Rhodes, Apollonius Paradoxographus, Apuleius, Aristotle, Athanasius the Great, Augustine, Basil the Great, Chius Eudemus (not identified), Claudianus, Claudius Aelianus, Ptolemy, Clemens of Alexandria, Diogenianus, Dionysius of Alexandria, Dionysius of Halicarnassus, Euripides, Eustathius of Antioch, Flavius Philostratus, Gaius Julius Solinus, Galen, Gregory of Nazianz, Hesychius of Alexandria, Hippocrates of Kos, Isidor of Seville, Isognous, John Chrysostomus, Ktesias of Knidos, Lucretius, Marcus Tullius Cicero, Nemesius of Emesa, Origen, (Ps.-)Orpheus (lapidary), Pedanius Dioscurides, Philon of Alexandria, Plato, Pliny the Elder, Plutarch, Priscianus, Proclus, Propertius, Prosper Tiro of Aquitaine, Rhemmius Fanninus, Rufinus, Sextus Empiricus, Sophronius Eusebius Hieronymus, Sotion of Alexandria, Themistius, Theodoretus, Theocritus, Theophilus, Theophrastus, Vergil, Zenobius (Sophist), Zenodotus of Ephesus.

65 The authors are: Etymologus, Eustathius of Thessalonike, Geoponica, Helladius Antinoupolitanus, John Tzetzes, Konstantin Manasses, Michael Psellus, Nikephoros Kallistu Xanthopulos, Suda, Theodorus Prodromus, Theophylact Simocatta. Tzetzes is also mentioned in Lelio Bisciola, Horarvm svbsecivarvm tomus. In Qvibvs Pleraqve Ex Philosophia, \& Encyclopaedia, atque omnibus ferè scientijs, ac tribus praecipuis linguis Hebraea, Graeca, Latina, non vulgaria explicata; adnotatis, emendatis, enucleatis, plurimis omnis generis scriptorum locis, vol. 2 (Cologne, 1618), 19-20; Mersenne, Quaestiones celeberrimae in Genesim, 548. They refer to John Tzetzes, Lycophronis Chalcidensis Alexandra, sive 
and early modern period make up the lion's share with 95 names (in Book 1 alone). ${ }^{66}$ Allacci's Apes urbanae (1633) testifies to this interest in the contemporary academic (and political) scene (particularly of Rome) by offering what might be called a prosopography of illustrious men (viri illustres) ${ }^{67}$

The sheer number of authors mentioned in De magnete is obvious on virtually any random page, in this case a discussion of the metaphorical use of such concepts as 'nutrition' or 'love' in order to account for magnetic attraction. ${ }^{68}$ On folio 18v (fig. 1), Allacci names no less than thirteen authors (Theophylact Simocatta, Achilles Tatius, Nemesius of Emesa, John Tzetzes, Gerolamo Cardano, Jean de Renou, Kaspar Schwenckfeld, Anselmus de Boodt, Marin Mersenne, Giovanni Costeo, Jakob Milich, Pliny the Elder, and Johann Daniel Mylius), offering literal quotations from nine, including three in Greek. ${ }^{69}$ Also

Cassandra ... Adiectus quoque est Ioannis Tzetazae Variarum Historiarum Liber, versibus politicis ab eodem Graecè conscriptus, \& Pauli Lacisii Veronensis opera ad verbum Latinè conversus, nec unquam antea editus, trans. Paulus Lacisius (Basel, 1546), 111. The Suda and the Geoponica are also mentioned several times by other authors with regard to their account of the magnet.

66 The authors are: Achilles Pirmin Gasser, Alessandro degli Angeli, Andreas Schott, Anselmus de Boodt, Antoine Mizauld, Camillo Leonardi, Celio Calcagnini, Celio Secondo Curione, Cesare d'Evoli, Christoph Entzelt, Collegium Conimbricense, Conrad Gesner, Cornelius Gemma, Curio Lancellotto Pasi, Daniel Furlanus, Daniel Heinsius, David Origanus, Ermolao Barbaro, Eustache Vignon, Famiano Strada, Fortunio Affaitati, Francesco Cattani da Diacceto, Francesco Imperato, Francesco Silvestri, Franciscus Carus (not identified, cf. fol. 209r), Franciscus Rueus, Gabrieler Falloppio, Garcia de Orta, Gaudenzio Merula, Gentian Hervet, Georg Agricola, Georg Joachim Rheticus, Georg Pictorius, Gerolamo Cardano, Giambattista della Porta, Giambattista Birelli, Giovanni Costeo, Giovanni Francesco Pico della Mirandola, Giovanni Gioviano Pontano, Gerolamo Fracastoro, Guillaume de Saluste du Bartas, Guillaume Dupuis, Heinrich Salmuth, Jacopo Zabarella, Jacques Daléchamps, Jakob Milich, Jan Gruter, Janus Cornarius, Jean Bodin, Jean Brodeau, Jean de Renou, Jean Du Choul, Jean Edouard Du Monin, Jean Filesac, Jean Roberti, Jean Ruel, Jean Taisnier, Jean-Jacques Boissards, Johann Daniel Mylius, Johann Israel de Bry, Johann Jacob Wecker, Johann Theodor de Bry, Johannes Kentmann, Johannes Kepler, Johannes Mathesius, Johannes Passeratius, Juan Luis Vives, Julius Caesar Scaliger, Kaspar Schwenckfeld, Levinus Lemnius, Lodovico Dolce, Lodovico Ricchieri, Marcellus Vergilius, Marin Mersenne, Marsilio Ficino, Martin Delrio, Matthias Untzer, Michael Maier, Oswald Croll, Paracelsus, Petrus Albinus, Petrus Arlensis de Scudalupis, Pierre Belon, Pietro Andrea Mattioli, Pietro Pomponazzi, Robert Constantin, Robert Fludd, Robert Hues, Rudolph Goclenius, Sebastian Münster, Simeone Maiolo, Steven Winand Pigge, Thomas Cajetan, Tycho Brahe, William Camden, William Gilbert.

67 Cf. Allacci, Apes Urbanae.

68 Cf. esp. Sander, "Nutrition and Magnetism." See also in LaGalla's De sympathia, fol. 61r, in Allacci Xxx.

69 Cf. Jean de Renou, Institutionum pharmaceuticarum libri 5. Quibus accedunt De materia medica libri 3. Omnibus succ. Officina pharmaceutica, sive antidotarium. (Paris, 1608), 128, 205; Jakob Milich and Pliny the Elder, C. Plinij liber secundus, De mvndi historia: diligenter 


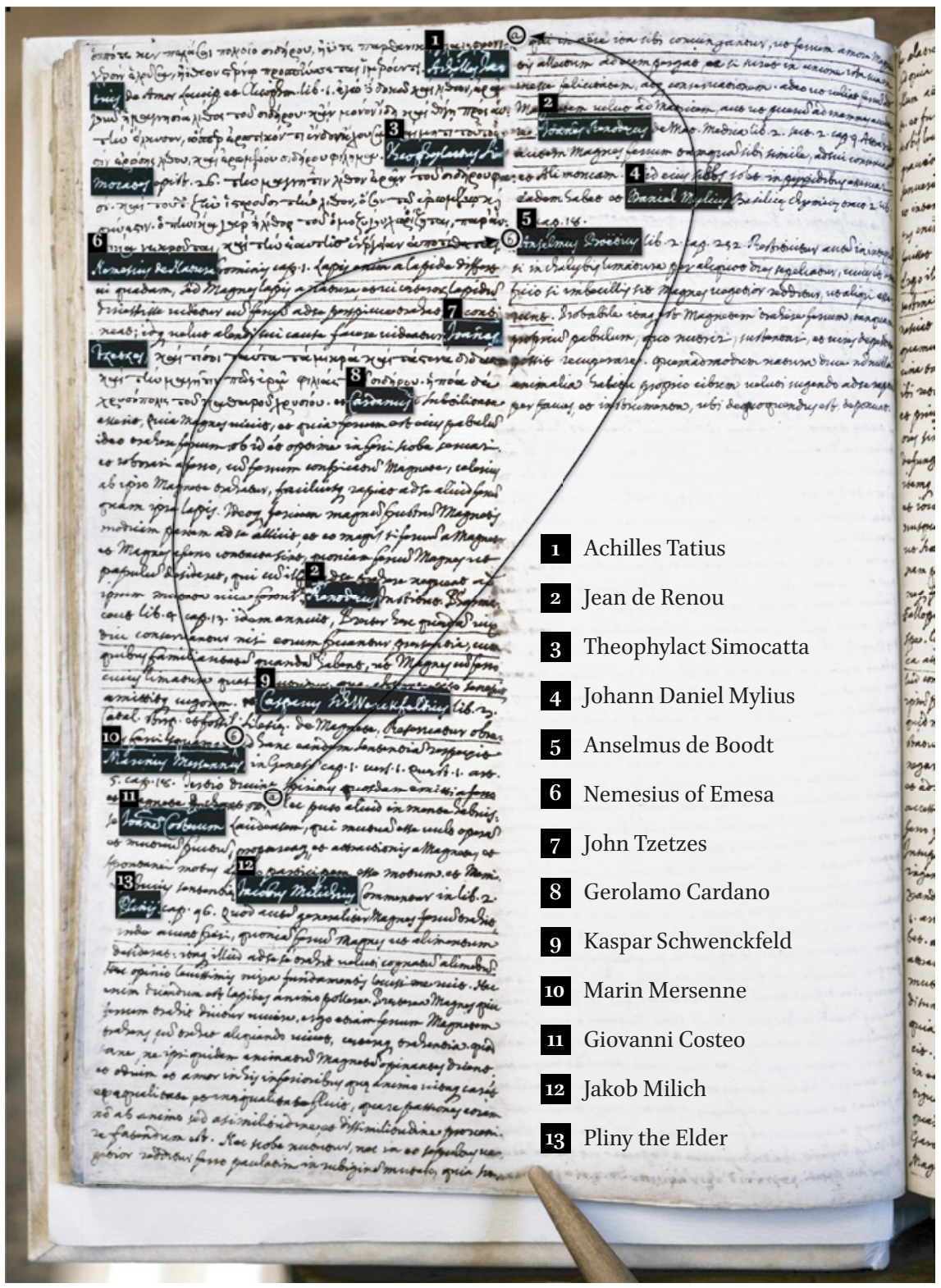

FIGURE 1 A page rich with references and quotations in Allacci's autograph of De magnete. SOURCE: ROME, BIBLIOTHECA VALLICELLIANA, ALLACCI LXXVII, FOL. $18^{\mathrm{v}}$. ORIGINAL PAGE DIMENSIONS: $267 \mathrm{MM} \times 200 \mathrm{MM}$. DESIGN BY VICTORIA BEYER 
interesting is Allacci's insertion of some of these references and quotations in a later stage, appending them to the blank right column and linking them to the main text by quasi-footnotes $(\mathrm{a}, \mathrm{b}, \ldots) .{ }^{70}$ Except those in Greek, Allacci highlights all literal quotations by underlining them.

Much of Allacci's doxographical and philological strategy is striking: Allacci quotes from Greek sources like no other author before him in order to enrich the physical and onomasiological knowledge of the magnet. Among the Byzantine authors, he relies partly on unedited sources, but often on the collections published by the Jesuit Andreas Schott in his Photii bibliotheca (1606) and in his Adagia sive proverbia Graecorum (1612). ${ }^{71}$ Regarding manuscript sources, Allacci mentions a different reading in Theophrastus's On Stones, which had been among the Palatina manuscripts, used by Daniel Heinsius for his Theophrastus edition of 1613 , and was finally brought to Rome. ${ }^{72} \mathrm{He}$ also quotes from a lapidary called Dactylotheca by Lancellotto Pasi of Ferrara, written in verses, which was completed around 1500 , but has yet to be published. ${ }^{73}$ An

conscriptis, et postremo ab autore recognitis, et multis in locis auctis; Anno ... 1552; Una cum indice utili (Frankfurt, 1553), 396; Achilles Tatius, Leucippe and Clitophon, ed. Ebbe Vilborg, Studia Graeca et Latina Gothoburgensia 1 (Stockholm, 1955), 50; Theophylact Simocatta, Theophylacti Simocatae epistulae, ed. Joseph Zanetto (Leipzig, 1985), 15; John Tzetzes, Ioannu tu Tzetzu Biblion historikēs tēs dia stichōn politikōn alpha de kalumenēs: Graece = Joannis Tzetzae historiarum variarum chiliades, ed. Gottlieb Kiessling (Hildesheim, 1963), 145; Nemesios of Emesa, De natura hominis liber utilissimus (Lyon, 1538), 10; Kaspar Schwenckfeld, Stirpium \& fossilium Silesiae catalogus. In quo praeter etymon, natales, tempus; natura \& vires cum varijs experimentis assignantur: concinnatus per Casparum Schuuenckfelt. (Leipzig, 1600), 384; Marin Mersenne, Quaestiones celeberrimae in Genesim, 948; Anselmus de Boodt, Gemmarvm et lapidvm historia qua non solum ortus, natura, vis \& precium, sed etiam modus quo ex iis olea, salia, tincturae, essentiae, arcana \& magisteria arte chymica confici possint, ostenditur: opvs principibvs, medicis, chymicis, physicis, ac liberalioribus ingeniis vtilissimum: cum variis figuris, indiceq. duplici \& copioso (Hannover, 1609), 219.

70 The order of a, b, etc., does correspond to the order in which Allacci made these additions, not to the order in which they appear in the main text, as is clearly visible in fol. $18 \mathrm{v}$.

71 Cf. Andreas Schott, ed, Photii bibliotheca: siue lectorum à Photio librorum, recensio, censura atque excerpta, philologorum, oratorum, historicorum, philosophorum, medicorum, theologorum (Augsburg, 16o6), 56, 62, 255, 541; Andreas Schott, ed, Adagia sive proverbia Graecorvm ex Zenobio seu Zenodoto, Diogeniano \& Svidae collectaneis (Antwerps, 1612), 85, 218, 611 .

72 See fol. 133v: "Codex mancus Theophrasti Heintianus, ex Codice Manuscripto Palatinae Bibliothecae, quae nunc in Vaticana asservatur." It probably refers to the incomplete Codex Vaticanus 1305 (cf. the corresponding manuscript in Vatican City, Biblioteca Apostolica Vaticana). See also Theophrastus, On Stones, ed. John F. Richards and Earle Radcliffe Caley (Columbus, 1956).

73 Cf. Lynn Thorndike, "Some Unpublished Minor Works Bordering on Science Written in the Late Fifteenth Century," Speculum 39, no. 1 (1964): 90-92. The manuscript is held 
anonymous Greek source for the magical use of the magnet, who remains unidentified, also received Allacci's attention and is quoted in De magnete. ${ }^{74}$

The selection of contemporary authors is astonishing, attesting to a full overview of the printed books of his time. Among the authors cited are a striking number of theologians and less-known writers, which makes Allacci's book a vital repertory for modern scholarship on the history of magnetism. The most important, and most frequently cited, sources are clearly the lapidaries of Theophrastus, Pliny, Camillo Leonardi (1502), Anselmus de Boodt (1609); the 'mirabilia'-collections of Antoine Mizauld (1554-1566); and the magical treatise of Petrus Arlensis de Scudalupis (1610). ${ }^{75}$ However, better known authors such as Petrus Peregrinus, Gerolamo Cardano, and Giambattista della Porta are rarely mentioned. ${ }^{76}$ Characteristically, Allacci refers to William Gilbert only once, in the first book. ${ }^{77}$ This disregard cannot be explained by theological avoidance; Gilbert was a Copernican and already in 1609 was attacked by Catholics. ${ }^{78}$ Allacci mentions without hesitation other authors considered heterodox or even condemned, such as Joachim Rheticus, Sebastian Münster, Jakob

in Vatican City, Biblioteca Apostolica Vaticana, Ott. lat. 1957, fols. 1r-84r. In Allacci, see fols. 9 r, 151 ir.

74 See fol. 243r. This work is not included in Fernand de Mély, Les Lapidaires de l'Antiquité et du Moyen Age, 3 vols. (Paris, 1896-1902); Robert Halleux and Jacques Schamp, eds., Les Lapidaires grecs (Paris, 1985). For another example, see fol. $368 \mathrm{r}$.

75 Theophrastus, On Stones; Theophrastus and Daniel Furlanus, Theophrasti Eresii, Peripateticorum post Aristotelem principis pleraque antehac Latinè nunquam, nunc Graecè \& Latinè simul edita (Hannover, 1605); Pliny, Historiae naturalis Libri XXXVII, ed. Alessandro Benedetti (Venice, 1507); Pliny, Naturalis historia. Libri XXXI-XXXVII, ed. Ludwig van Jan and Carl Mayhoff, vol. 5, Bibliotheca scriptorum Graecorum et Romanorum Teubneriana (Leipzig, 1897); Camillo Leonardi, Speculum lapidum (Venice, 1502); Anselmus de Boodt, Gemmarvm et lapidvm historia; Antoine Mizauld, Catalogi septem sympathiae et antipathiae, seu concordiae et discordiae rerum aliquot memorabilium etc. (Paris, 1554); Antoine Mizauld, Memorabilium aliquot naturae arcanorum sylvula, rerum variarum sympathias et antipathias, seu naturales concordias et discordias, libellis duobus complectens (Paris, 1554); Mizauld, De arcanis naturae; Antoine Mizauld, Secretorum agri enchiridion primum, hortorum curam ... libris tribus pulcherrimis complectens (Paris, 156o); Antoine Mizauld, Memorabilium, utilium, ac jucundorum centuriae novem, in aphorismos arcanorum omnis generis locupletes, perpulchrè digestae (Paris, 1566); Camillo Leonardi and Petrus Arlensis de Scudalupis, Speculum lapidum Camilli Leonardi. Cui Accessit Sympathia septem metallorum ac septem selectorum lapidum ad planetas. D. Petri Arlensis de Scudalupis (Paris, 1610).

76 On Cardano's treatise on magnetism, cf. Cardano, De subtilitate, 1550, 157v-161v; Gerolamo Cardano, De subtilitate. Libri 1-7, ed. Elio Nenci, vol. 1 (Milan, 2004), 664-77. Allacci refers to the edition of Petrus Peregrinus, De Magnete, Seu Rota Perpetui Motus, Libellus, ed. Achilles Pirmin Gasser (Augsburg, 1558).

77 See fols. $16 \mathrm{r}, 17 \mathrm{v}$.

78 Cf. Sander, “Early-Modern Magnetism," 328. 
Milich, and Johannes Kepler. ${ }^{79}$ Most likely, Allacci wanted to demonstrate to his readers that luminaries such as Gilbert and della Porta did not dominate the discourse around ${ }_{1625}$, when other sources were available. Moreover, Allacci's doxography has no parallel in LaGalla's De sympathia, which did quote several authors, but not with the same depth as his student, and none of them is quoted in Greek. With the exception of the authors involved in the weapon salve controversy, which will be sketched below, LaGalla mostly relies on authors of antiquity, but none of the seventeenth century. ${ }^{80}$

The second book of De magnete is much shorter and less original. Here, too, quoting and copying dominate, not experimenting. The first three of the nine chapters are devoted to the invention of navigation and the magnetic compass. ${ }^{81}$ Allacci obviously read virtually everything, shining again as a learned doxographer. While LaGalla hardly mentions the pointing north of the compass needle, chapters four to seven of De magnete deal extensively with the topic, in particular its declination. ${ }^{82}$ Causal hypotheses are discussed as well; yet as in the discussions about the cause of attraction, Allacci remains skeptical. ${ }^{83}$ The last two chapters are devoted to instruments such as the nautical and the geodetic compass, but also — somewhat surprisingly — to the magnetic perpetuum mobile. ${ }^{84}$

79 For these authors, see the indices in J. M. de Bujanda et al., eds., Index des livres interdits, 11 vols. (Québec, 1984-2002); Ugo Baldini and Leen Spruit, eds., Catholic Church and Modern Science: Documents from the Archives of the Roman Congregations of the Holy Office and the Index Vol. 1: Sixteenth-Century Documents, 4 vols, Fontes Archivi Sancti Officii Romani/ Series Documentatorum Archivi Congregationis pro Doctrina Fidei 5 (Rome, 2009).

8o LaGalla, e.g., refers to Alexander of Aphrodisias, Aristotle, Ptolemy, Galen, Hippocrates of Kos, Lucretius, Marcus Tullius Cicero, Plato, Pliny the Elder, Theophrastus, Albertus Magnus, Thomas Aquinas, Thomas de Vio Cajetan, Gerolamo Cardano, Gerolamo Fracastoro, Giambattista della Porta, Pietro Pomponazzi, Jean Fernel, Jean Bodin, Lodovico Boccadiferro; Marsilio Ficiono. LaGalla, however, often invoked contemporaries know to him in person, cf. n. 121.

81 Cf. also Elio Nenci, "L'inventione del bossolo da navigare,' e le scoperte geografiche," in Bernardino Baldi (1553-1617) studioso rinascimentale: poesia, storia, linguistica, meccanica, architettura: atti del convegno di studi di Milano, 19-21 novembre 2003, ed. Elio Nenci, Filosofia e scienza nell'età moderna 62 (Milan, 2005), 233-46; Concetta Pennuto, "Reinventare l'oggetto: Girolamo Fracastoro e il bossolo dei naviganti," Quaderni storici 1 (2009): 67-92.

82 In De sympathia, cf. fols. 61r, 74r, in Allacci xxx. As a starting point, see Balmer, Erdmagnetismus; Art Roeland Theo Jonkers, Earth's Magnetism in the Age of Sail (Baltimore, 2003).

83 LaGalla criticizes the theory of magnetic mountains, cf. fol. 74r, in Allacci xxx.

84 On the non-nautical compasses, cf. Hans-Günther Körber, Zur Geschichte der Konstruktion von Sonnenuhren und Kompassen des 16. bis 18. Jahrhunderts, Veröffentlichungen des Staatlichen Mathematisch-Physikalischen Salons 3 (Berlin, 1965). On the magnetic 
Allacci's sources in the second book overlap, of course, with those in book one, but in the context of navigational history he also mentions the voyages of Amerigo Vespucci and Christopher Columbus. ${ }^{85}$ Other important sources for the context of the second book are: Celio Calcagnini's De re nautica (1544), Willebrord Snellius's Tiphys batavus (1624), Robert Hues's Tractatus de globis (1624), Johann Georg Schönberger's Exegeses fundamentorum gnomonicorum (1615) as well as Hugo Grotius's Latin translation ( $\Lambda$ IMENEYPETIKH) of Simon Stevin's De havenvinding (1599). ${ }^{86}$ Gilbert again plays a very minor role in this nautical and geomagnetic context; his geomagnetic theory is presented only on the basis of its criticism in Tommaso Campanella's De sensu rerum et mag$i a .{ }^{87}$ Allacci was certainly not Gilbert's biggest fan. What is special about this second book, however, is that Allacci copied not only text, but also images and diagrams: a split magnetic stone from Arlensis's work, an iron needle on the magnet, and a visual instruction of a magnetic land-surveying technique from Boodt's lapidary, two navigational instruments from Stevin's work (fig. 2-4), and the magnetic perpetuum mobile from both Cardano's De rerum varietate (1557) and Achilles Pirmin Gasser's edition of Peregrinus (1558). ${ }^{88}$ The accuracy of these drawings attests to Allacci's graphic skill and provides a visual dimension to his anthology. He used a compass to draw the circles; in the case of the magnetic compass rose for Stevin's first instrument (haloscopon), he even commented on how the degrees must be divided around the circumference (fig. 3). This demonstrates that, although Allacci 'just copies' these diagrams, he grasped what the figures must have meant in their original context. All of Allacci's drawings are copied at larger scale than the originals. The two circles of the two perpetua mobilia, which are designed as wheels and appear recto verso in his manuscript, are drawn in such a way that their two circumferences

perpetuum mobile, cf. Andreas Kleinert, "Wie funktionierte das Perpetuum mobile des Petrus Peregrinus?," NTM Zeitschrift für Geschichte der Wissenschaften, Technik und Medizin 11, no. 3 (2003): 155-70; Dietrich Lohrmann, "Idee und Wirklichkeit des Perpetuum mobile im Mittelalter," Technikgeschichte 73 (2006): 227-51.

85 See fols. 52 r, 54 r.

86 Allacci also mentions, among other, Luca Gaurico, Martín Cortés, Toussaint de Bessard, Tommaso Campanella, Alvise Cadamosto, Gemma Frisius.

87 Tommaso Campanella, De sensu rerum et magia, libri quatuor, pars mirabilis occultae philosophiae, ubi demonstratur, mundum esse Dei vivam statuam, beneque cognoscentem (Frankfurt, 1620), 30-35.

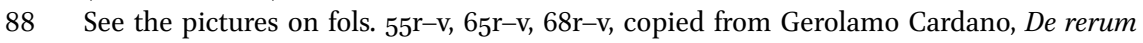
varietate libri XVII adiectus est capitum, rerum \& sententiarum notatu dignissimarum index (Basel, 1557), 374; Petrus Peregrinus, De Magnete; Leonardi and Arlensis de Scudalupis, Sympathia septem metallorum, 458; Boodt, Gemmarvm et lapidvm historia, 221, 23233; Simon Stevin, Limeneuretikē, sive, portuum investigandorum ratio, trans. Hugo Grotius (Leiden, 1599), 17, 19. 


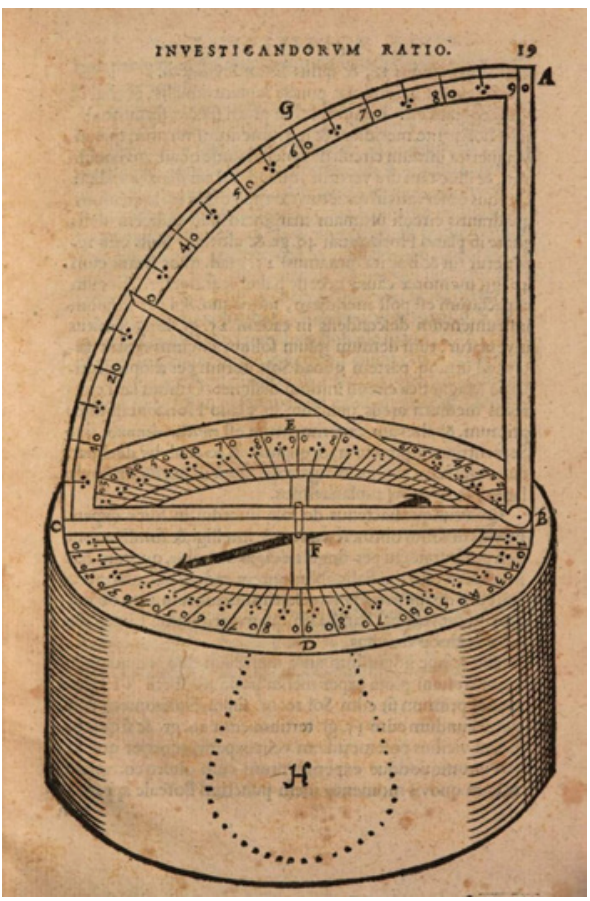

FIGURE 2

Navigational instrument (second) as shown in Simon Stevin's De havenvinding/ $\Lambda$ IMENEYPETIKH (1599) SOURCE: BAYERISCHE STAATSBIBLIOTHEK MÜNCHEN, RES/4 A.GR.A. 114. DIMENSIONS OF THE IMAGE: $191 \mathrm{MM} \times$ $118 \mathrm{MM}$

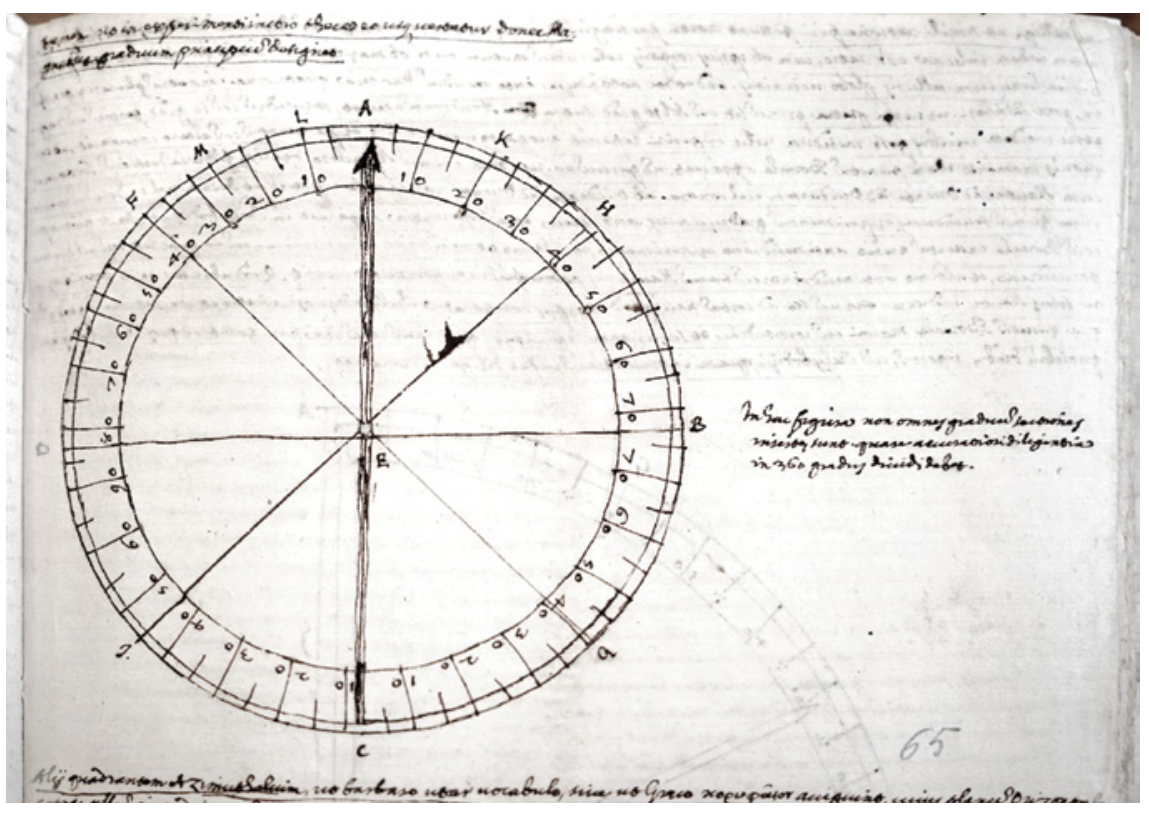

FIGURE 3 Allacci's copy of Stevin's first instrument with a marginal note on how to divide the degrees

SOURCE: ROME, BIBLIOTHECA VALLICELLIANA, ALLACCI LXXVII, FOL. $65^{\text {R }}$. DIMENSIONS OF THE IMAGE: $123 \mathrm{MM} \times 123 \mathrm{MM}$. BLACK INK ON PAPER 


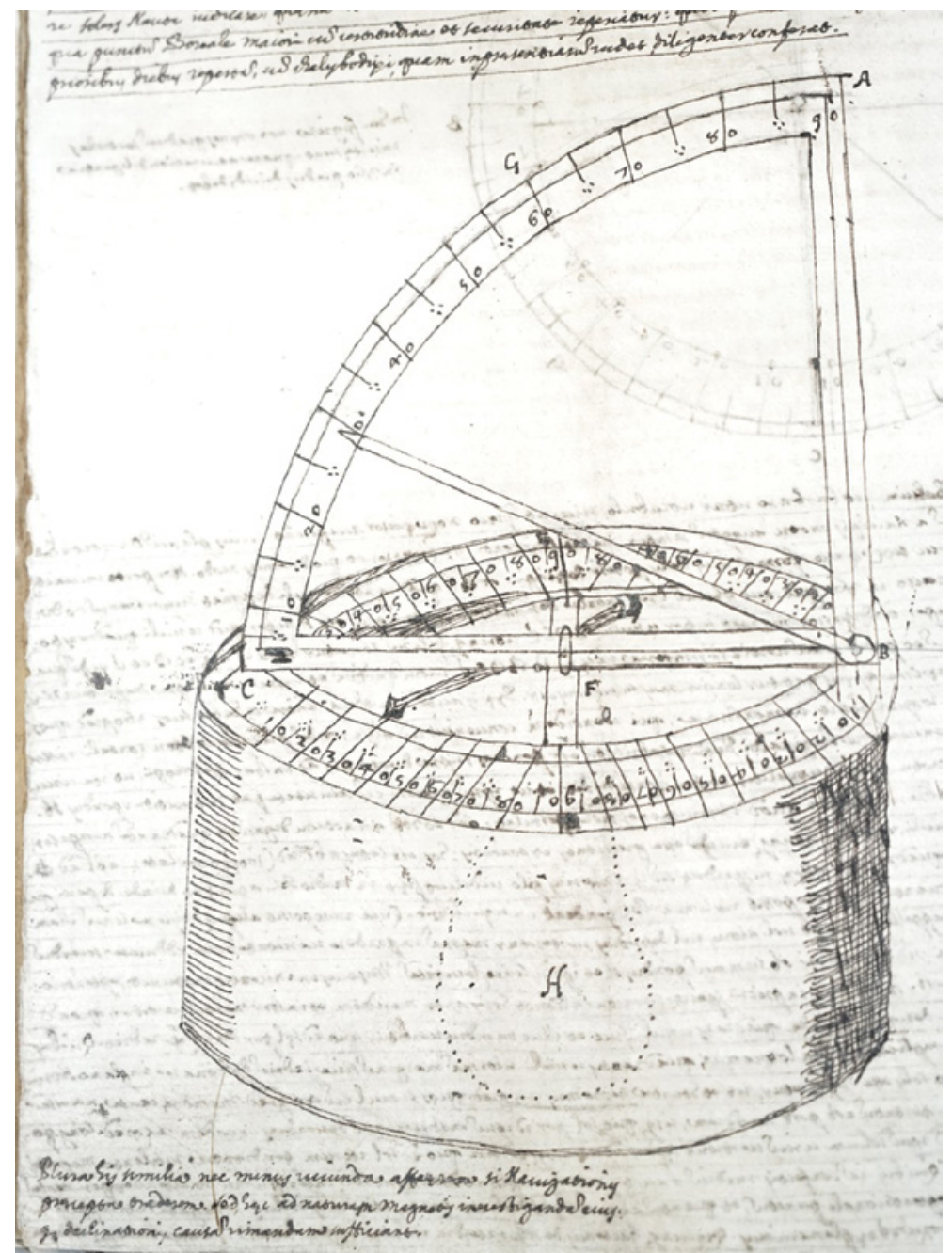

FIGURE 4 Allacci's copy of Stevin's second instrument SOURCE: ROME, BIBLIOTHECA VALLICELLIANA, ALLACCI LXXVII, FOL. $65^{\mathrm{v}}$. DIMENSIONS OF THE IMAGE: $175 \mathrm{MM} \times 127 \mathrm{MM}$. BLACK INK ON PAPER

perfectly match in dimensions and page positions. Allacci, then, only needed to trace them with black ink on either side of the page in order to integrate the circles into both of these perpetua mobilia diagrams. ${ }^{89}$ Finally, it is interesting that the apograph, i.e., the copy made by Vernazza, omitted the entire text of book two but carefully copied the images. Vernazza did not trace them; he even tried to make refinements, e.g., by transforming the compass needle into an arrow (fig. 5). He also shaded in Stevin's second cylindrical instrument (an

89 Moreover, the scale labelling of one of these two circles is rotated by $90^{\circ}$. 


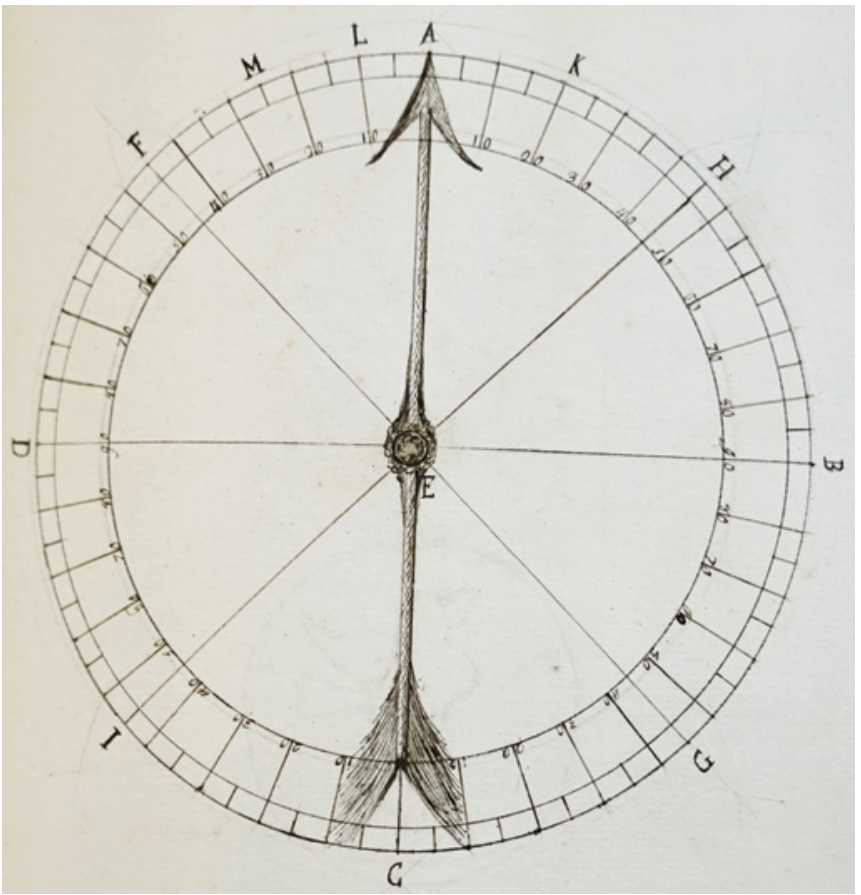

FIGURE 5 Vernazza's copy of Allacci's copy of Stevin's first instrument SOURCE: ROME, BIBLIOTHECA VALLICELLIANA, ALLACCI LXXVII, FOL. $116^{\mathrm{R}}$. DIMENSIONS OF THE IMAGE: $123 \mathrm{MM} \times 123 \mathrm{MM}$. BLACK INK ON PAPER

azimuth quadrant) with graywash instead of ink-shadow hatching, creating a more naturalistic image (fig. 6). ${ }^{90}$ It is thus very clear that Vernazza considered these images to be important.

The third book of Allacci's De magnete may be judged the most original contribution in terms of content, albeit it is also the book that owes the most to LaGalla's De sympathia. In the first of the ten chapters, Allacci presents the medical use of the magnet, displaying good knowledge of pharmacological literature since antiquity. ${ }^{91}$ Here, he follows an assumption very similar to

9o The smaller images on fols. $55^{\mathrm{r}-\mathrm{v}}$ were not copied by Vernazza in the apograph.

91 This aspect is mostly missing in De sympathia by LaGalla. On medieval pharmacology, cf. John M. Riddle, "LITHOTHERAPY in the Middle Ages...: Lapidaries Considered as Medical Texts," Pharmacy in History 12, no. 2 (1970): 39-50; Helena M. Paavilainen, Medieval Pharmacotherapy, Continuity and Change Case Studies from Ibn Sina and Some of His Late Medieval Commentators, Studies in Ancient Medicine 38 (Leiden/Boston, 2009). The written chapter numbers of Allacci's third book are misleading as two subsequent chapters are called the "fifth chapter." 


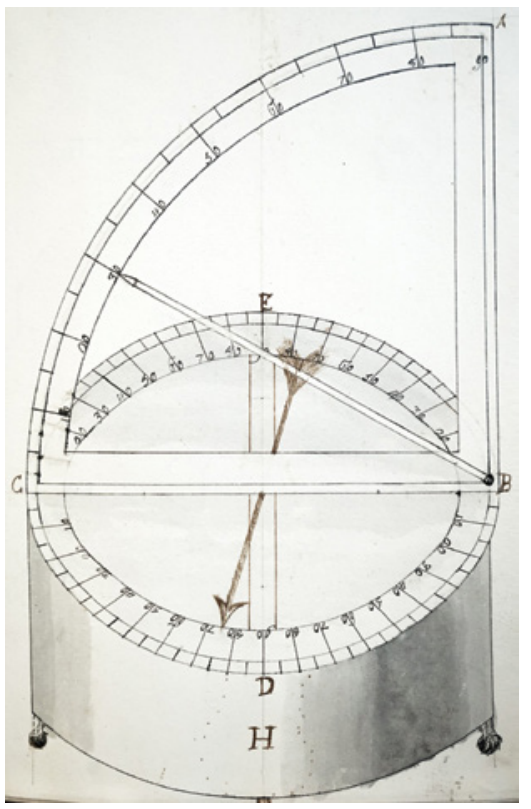

FIGURE 6

Vernazza's copy of Allacci's copy of Stevin's second instrument SOURCE: ROME, BIBLIOTHECA VALLICELLIANA, ALLACCI LXXVII, FOL. $117^{\mathrm{R}}$. DIMENSIONS OF THE IMAGE: $232 \mathrm{MM} \times 150 \mathrm{MM}$. BLACK AND BROWN INK, GRAYWASH ON PAPER

Gilbert's. ${ }^{92}$ On the one hand, the magnetic stone attracts. This power, for Allacci, is owing to its 'spiritus.' On the other hand, the magnet is also a mineral substance, an effective remedy owing to its elemental mixture. ${ }^{93}$ In this way Allacci explains why hematite and magnet are medically interchangeable, although hematite does not attract iron; both have the same 'elementary mixture,' as relevant for pharmacology. ${ }^{94}$ With this account, Allacci remains clearly within the theoretical framework of Galenism, although he does not confess himself thus or deal with Galenic medicine in any length. ${ }^{95}$ Allacci also mentions that some authors claim magnets to be the cause of 'melancholy,'

92 Cf. DM I, 14-15, and Allen G. Debus, "Robert Fludd and the Use of Gilbert's De Magnete in the Weapon-Salve Controversy," Journal of the History of Medicine and Allied Sciences 19, no. 4 (1964): 389-417; Gad Freudenthal, "Theory of Matter and Cosmology in William Gilbert's De Magnete," Isis 74, no. 1 (1983): 22-37.

93 See fol. 256r: "Est et alia ipsius Magnetis actio, et facultas non a spiritu illius, qua magnes est, sed a materia et elementis certo quodam ordine ita unitur."

94 See esp. Galen's De succedaneis, cf. Radl, Der Magnetstein in der Antike, 74. Pliny and Dioscorides also relate hematite and magnets to each other, cf. Radl, 55, 58, 131. For an early modern account, cf. Agricola, Opera, 251.

95 As a starting point, see Philip J. van der Eijk, Medicine and Philosophy in Classical Antiquity: Doctors and Philosophers on Nature, Soul, Health and Disease (Cambridge/New York, 2005), 286-88; Sabine Vogt, "Drugs and Pharmacology," in The Cambridge Companion to Galen, ed. Robert James Hankinson, Cambridge Companions to Philosophy (Cambridge/ New York, 2008), 304-22. 
while others believe them to cure 'melancholy.' ${ }^{66}$ Both uses, according to $\mathrm{Al}$ lacci, are probably correct, because magnets in different regions differ in their elementary mixture; the Indian magnet, for example, had allegedly different medical capabilities than the European magnet. ${ }^{97}$

The second chapter is devoted mainly to the spagyric recipes of the Paracelsian tradition, which contained magnets or their powder. ${ }^{98}$ Here he also mentioned Paracelsus's famous magnetic emplastrum, 'Oppodeltoch. ${ }^{.99}$ Chapters three to six are devoted to the weapon salve. This remedy of pseudo-Paracelsian origin promised to heal wounds at a distance by applying a medicine containing the blood of the wound only to the weapon that inflicted it. The first textual traces of this salve can be found in the late sixteenth century, but a full-blown controversy about it began only at the beginning of the seventeenth century, involving dozens of treatises and participants throughout Europe. ${ }^{100}$ Roughly,

96 Cf., e.g., Pietro d'Abano, Conciliator controuersiarum, quae inter philosophos et medicos versantur (Venice, 1565), 264r; 265v. Cf. also Ferdinando Ponzetta, Libellus de venenis (Rome, 1521), lib. 2, tr. 4, c. 5; Pierre Bersuire, Reductorii moralis, 481; Ulisse Aldrovandi, Musaeum metallicum: in libros IIII distributum (Bologna, 1648), 163; Gerolamo Cardano, Opera Omnia (Lyon, 1663), vol. 7, 312.

97 See fol. 257v: "Ego vero non dubitarim ambos hasce opiniones quamvis contrariae videantur, vera affirmare." For Gilbert, the medical effect depends on the individual specimen of a magnet, since it is rarely found in its pure form, but each is mixed with other minerals depending on its origin and can therefore cause opposite effects. For example, the Chinese magnet is able to unfold its medicinal effect for digestion, but such an effect is not "magnetic" (non virtute magnetica), but depends above all on the mineral admixtures of the specimen (vitio illius venae). Cf. Gilbert, De magnete, 77.

98 On Paracelsus and magnetism, cf. esp. Hans Rutschow, “Über den Magnetismus bei Paracelsus" (Inaugural-Diss., Univerität Köln, 1965). For magnets in recipes, see, e.g., Paracelsus, Medizinische, naturwissenschaftliche und philosophische Schriften, ed. Karl Sudhoff, Sämtliche Werke [von] Theophrast von Hohenheim gen. Paracelsus 1 (Hildesheim, 19191933), vol. 2, 388, 437; vol. 3, 179, 355; vol. 5, 107, 111, 118, 120, 219, 275; vol. 6, 470; vol. 10, 571.

99 Cf. Paracelsus, Schriften, vol. 10, 361 . Cf. also Jürgen Reichling, Arends Volkstümliche Namen der Drogen, Heilkräuter, Arzneimittel und Chemikalien, 19th ed. (Berlin, 2012). On Paracelsus's magnetic recipes in pharmacopoeias, cf. Laurent Joubert, ed, Pharmacopoea (Lyon, 1579), 290; Collegium Medicorum (Bergamo), ed, Pharmacopoea, seu de usitatiorum medicamentorum componendorum ratione liber (Bergamo, 1580), 322; Adolf Occo, ed, Pharmacopoea pro Republica Augustana (Augsburg, 1640), 296, 299, 300, 304, 318; Pharmacopoea Bruxellensis jussu ampl. Senatus edita (Bruxelles, 1641), 164; Johann Schröder, Pharmacopoeia medico-chymica sive thesaurus pharmacologicus (Ulm, 1641), 138 (lib. 1), 39 (lib. 2).

100 On the origins of the salve, cf. Roberto Poma, "Hopliatria," discours savants sur la guérison magique" (Diss., A.N.R.T, 2005). Cf. also Gerhard Eis, Vor und nach Paracelsus: Untersuchungen über Hohenheims Traditionsverbundenheit und Nachrichten über seine Anhänger (Stuttgart, 1965), 34; Wolf-Dieter Müller-Jahncke, "Magische Medizin bei Paracelsus und den Paracelsisten: Die Waffensalbe," in Resultate und Desiderate der Paracelsus-Forschung, ed. Rudolph Hartmut and Peter Dilg, Sudhoffs Archiv, Beihefte 31 (Stuttgart, 1993), 46, n. 22. Allacci (fol. 295r) also doubts that Paracelsus invented the salve, as does LaGalla (fol. 
there were two camps; one opinion, held primarily by Protestants and followers of Paracelsus, claimed that the weapon salve-in the tradition of natural magic - was a technique to induce healing in a natural, quasi-magnetic way. Critics of this opinion, often Catholics, considered it a tool of the devil because efficacy, in their view, came only with the aid of demonic powers; therefore, to be condemned as illicit magic or 'superstition.' Several theological acts of censorship and inquisitional trials surrounding the salve ensued. ${ }^{101}$ The critics

96r, in Allacci xxx), mentioning that some ascribe the invention to Johann Isaac Hollandus. On the early debate between Rudolph Goclenius, Jean Roberti, and Johann Baptist van Helmont, cf. esp. Robert Halleux, "Le procès d'inquisition du chimiste Jean-Baptiste Van Helmont (1578-1644): les enjeux et les arguments," Comptes-rendus des séances de l'Académie des Inscriptions et Belles-Lettres 148, no. 2 (2004): 1059-86. For the ideological background, cf. Carlos Ziller Camenietzki, "Jesuits and Alchemy in the Early Seventeenth Century: Father Johannes Roberti and the Weapon-Slave Controversy," Ambix 48, no. 2 (2001): 83-101; Tonino Griffero, "Immagini contagiose. Malattia e cure magnetiche nella philosophia per ignem di Johann Baptist van Helmont," Rivista di estetica 15, no. 3 (2000): 29-32; Mark A. Waddell, "The Perversion of Nature: Johannes Baptista Van Helmont, the Society of Jesus, and the Magnetic Cure of Wounds," Canadian Journal of History 38, no. 2 (2003): 179-98. For more recent contributions in the Italian context, cf. Massimo Marra, "Per una Storia della Medicina Magnetica 1. Nullum agens agit in distans: le dispute sull'Unguento Armario," Anthropos \& Iatria. Rivista italiana di studi e ricerche sulle medicine antropologiche e di storia delle medicine 19, no. 1 (2016): 78-99; Massimo Marra, "Per una Storia della Medicina Magnetica 2. Nullum agens agit in distans: la comparsa della Polvere di Simpatia," Anthropos \& Iatria 20, no. 2 (2016): 73-91; Salvatore Ricciardo, "Dalla mumia agli effluvia. Cure magnetiche e weapon-salve nella medicina e nella filosofia naturale inglese alla metà del XVII secolo," in Di stelle, atomi e poemi: verso la Physis, ed. Enrico Giannetto and Salvatore Ricciardo, Ishtar studies 2 (Canterano, 2018), 39-66; Massimo Marra, "Per una Storia della Medicina Magnetica 3. Nullum agens agit in distans: la polemica Papin-Cattier sulla polvere di simpatia," Anthropos \& Iatria 20, no. 1 (2016): $75^{-88}$; Lucia De Frenza, "Storia moderna della calamita e della sua virtù medicinale," Atti e memorie 2 (2018): 151-60.

101 The earliest Protestant censorship is from Rotterdam (1594), cf. Johannes Reitsma and Sietse Douwes van Veen, eds., Acta der provinciale en particuliere synoden, gehouden in de noordelijke Nederlanden gedurende de Jaren 1572-1620. Band 1: Noord-Holland 1572-1608, vol. 1 (Groningen, 1892), 27. In 1598, the Inquisition in Naples censored the salve, cf. Baldini and Spruit, Catholic Church, vol. 2, 1563. In 1616 it was censored by the Inquisition again, cf. Lyke de Vries and Leen Spruit, "Paracelsus and Roman Censorship - Johannes Faber's 1616 Report in Context," Intellectual History Review 28, no. 2 (2017): 21. On the trial agains van Helmont, see Corneille Broeckx, "Interrogatoires du docteur J. B. van Helmont sur le magnétisme animal, publiés pour la première fois," Annales de l'Académie d'archéologie de Belgique 13 (1856): 306-50; Corneille Broeckx, "Notice sur le manuscrit Causa J. B. Helmontii, déposé aux archives archiépiscopales de Malines," Annales de l'Académie d'archéologie de Belgique 9 (1852): 277-327. In Dillingen, the salve was censored by Jesuits, cf. Ulrich Gottfried Leinsle, Dilinganae Disputationes. Der Lehrinhalt der gedruckten Disputationen an der Philosophischen Fakultät der Universität Dillingen 1555-1648, Jesuitica 11 (Regensburg, 2006), 323, n. 140. Cf. also Laurenz Forer and Georg Mai, Dispvtatio Philosophica, De 
denied that the salve could work 'magnetically,' or in analogy to the magnet. The central issue of the debate was the notion of action at a distance, which was taken to be an absurdity both in Aristotelian and in corpuscular physics. ${ }^{102}$ In the natural world, two bodies, in order to act upon each other, need some sort of contact, which, they argued, was not the case in the weapon salve. Defenders of the salve, on the other hand, pointed out that magnets, for one, act on iron without physical contact; thus either the axiom of 'actio in distans non datur' is invalid, or other forms of non-physical contact must be taken into account. Here, concepts such as 'sympathy, 'virtual contact,' or 'astrological influences' were employed, opening the floodgates to a debate not only about the salve, but about the metaphysical foundations of nature and its powers.

Both LaGalla and Allacci defend the salve which, given their Catholic background, is quite noteworthy. Although a complete analysis of their positions awaits further investigation, a brief sketch is offered, since both authors have eluded treatment despite the vast literature on the topic. For Allacci, the salve

Magnete Sive Hercvleo Lapide (Ingolstadt, 1618), 27. Jesuits repeated the censorship until 1705, cf. Georg Michael Pachtler, ed, Ratio studiorum et institutiones scholasticae societatis Jesu, Monumenta Germaniae paedagogica 2, 9, 5, 16 (Berlin, 1887-1894), III, 94; José Luis Orella Unzue, "Un elenco jesuitico de proposiciones filosoficas (1696-1705)," Pensamiento 23 (1967): 290. In the Spanish Index Librorum Prohibitorum the salve was a target as well, cf. Antonio Zapata, Novus index librorum prohibitorum et expurgatorum (Seville, 1632), $571,669,845$.

102 On the issue of action at a distance, cf. Francis J. Kovach, "Action at a Distance in Duns Scotus and Modern Science," in Regnum Hominis et Regnum Dei: Acta Quarti Congressus Scotistici Internationalis, ed. Camille Bérubé, vol. 1, Studia Scholastico-Scotistica 6 (Rome, 1978), 477-9o; Francis J. Kovach, "The Enduring Question of Action at a Distance in Saint Albert the Great," The Southwestern Journal of Philosophy 10, no. 3 (1979): 161-235; André Goddu, "William of Ockham's Arguments for Action at a Distance," Franciscan Studies 44 (1984): 227-44; Francis J. Kovach, "Action at a Distance in St. Thomas Aquinas," in Thomistic Papers II, ed. Leonard Kennedy and Jack C. Marler (Houston, 1986), 85-132; Francis J. Kovach, "Aquinas Theory of Action at a Distance: A Critical Analysis," in Scholastic Challenges to Some Mediaeval and Modern Ideas, by Francis J. Kovach (Stillwater, 1987), 149-77; Max Jammer, Concepts of Force: A Study in the Foundations of Dynamics (Mineola, 1999); Mary B. Hesse, Forces and Fields: The Concept of Action at a Distance in the History of Physics (Mineola, 2005); Thomas Buchheim, "Effective Primary Causes: The Notion of Contact and the Possibility of Acting without Being Affected in Aristotle's De Generatione et Corruptione," in Reading Ancient Texts. Volume II: Aristotle and Neoplatonism, ed. S. SternGillet and K. Corrigan, Brill's Studies in Intellectual History 162 (Leiden, 2007), 65-96; Silvia Parigi, "I gesuiti e l'azione a distanza," in Cristoforo Clavio e la cultura scientifica del suo tempo atti del convegno tenutosi presso il Liceo "Ennio Quirino Visconti," 18 ottobre 2012, ed. Paola Vasconi (Rome, 2015), 93-102; Xiaona Wang, "Francis Bacon and Magnetical Cosmology," Isis 107, no. 4 (2016): 707-21; Yoshitaka Yamamoto, The Pull of History: Human Understanding of Magnetism and Gravity through the Ages (Hackensack, 2018). 
is not a remedy containing magnetic substances; rather, it has a power similar to the that of the magnet. ${ }^{103}$ Yet, whereas the magnet has only one simple power, namely to attract iron, the weapon salve has many. ${ }^{104}$ Allacci also discusses the essential theories of the supposed effectiveness of the weapon salve, for example those relating to the so-called 'mumia,' an essential concept in Paracelsian theories. ${ }^{105}$ His detailed portrayal of the contemporary weapon salve controversy takes the form of a disputation, thus clearly following in the footsteps of LaGalla's work, which has the same structure. ${ }^{106}$ First, they present the opponents' contra-argument; then they explain their own pro-position; finally they object to the contra-arguments. Both are, however, clearly opposed to the proponents of the weapon salve who, with the help of superstitious techniques such as spells, incantations, or astrology, sought to justify the effectiveness of the weapon salve. ${ }^{107}$

According to the Vatican librarian Allacci, however, the weapon salve is not to be condemned eo ipso as illicit magic — as he readily condemned some 'superstitious' usages of the magnet discussed in book one. ${ }^{108}$ Above all, the contra-party's conclusion that the salve is 'superstitious' or demonic because it presupposes an 'actio in distans' is, according to Allacci, untenable and unworthy of any philosopher. ${ }^{109}$ LaGalla makes a similar point. ${ }^{110}$ To explain this

103 See fol. 294r: "De curationibus agamus, in quibus Magnes aliquam sibi partem vindicat, necesse est, ut etiam de hoc unguento nonnulla disseramus."

104 See fol. 294v: "Magnetis effectus unus et simplex est, attractio videlicet ferri. Unguenti multiplex [...]."

105 Roberto Poma, Magie et guérison: la rationalité de la médecine magique, XVIe-XVIIe, Universités/domaine littéraire (Paris, 2009), 68-118. For an account of the alchemist Joachim Tancke, cf. Bruce T. Moran, The Alchemical World of the German Court: Occult Philosophy and Chemical Medicine in the Circle of Moritz of Hessen, 1572-1632, Sudhoffs Archiv, Beihefte 29 (Stuttgart, 1991), 138-40. Cf. also LaGalla's De sympathia, fol. 52r, in Allacci Xxx.

106 Cf. LaGalla's De sympathia, fols. 84r-96r, in Allacci xxx.

107 See fol. 321v: "Nota lector ut etiam superius unnui rationem huius unguenti conficiendi quam tradit Goclenius, Crollius, Mylius aliique nonnulli multis illisque pessimis."

108 Cf. n. 48 and 49.

109 See fol. 33or: "Et ratio de actione in distans, et consequenter operatione extra nature ambitum, unde superstitionem concludunt, vana omnino est, et philosopho vero indigna." See also fol. 417r: "Quare unguentum armarium propter actionem in distans infirmari non potest, nec damnari tamquam superstitiosum." Cf., e.g., for a directly opposite argument, Cabeo, Philosophia magnetica, 304.

110 Cf. LaGalla's De sympathia, fol. 93v, in Allacci xxx: "Quasi argumentum hoc de actione in distans, iudicio meo, nihil contra unguneti concludit." Cf. also ibid., gir: "Multi sunt quae arcano modo agunt in distans, et sive contactu, propriis et naturalibus viribus, sive Daemonis $[\ldots] . "$ 
alleged action at a distance, both refer to the philosophical, even Aristotelian, concept of 'virtual contact,' i.e., a non-physical causation. ${ }^{111}$ The ointment does not work through a corporeal quality, but through an immaterial substance. ${ }^{112}$ The existence of an 'actio in distans,' on the other hand, is empirically evidentthere are many examples of this according to LaGalla and Allacci. ${ }^{113}$ Already earlier, Allacci had stressed that bad physicians only copied from others and neglected their own experiences, whereas the physician begins exactly where the philosopher ends, as the saying goes. ${ }^{114}$ Allacci thus appears here as an empiricist, even if he hardly attempts to prove the effectiveness of the weapon salve by his own observations or therapies-relying instead on reports of others.

This quasi-empiricism is also apparent in the last three chapters. In this concluding section, Allacci no longer deals with the weapon salve or the

111 See fol. 334r. Cf. LaGalla's De sympathia, fol. 93r, in Allacci xxx. Cf. similarly Forer and Mai, Dispvtatio Philosophica, De Magnete Sive Hercvleo Lapide, 18; Theatrum sympatheticum auctum, 416, 569, 594; William Foster, Hoplocrisma Spongus, or a Sponge to Wipe Away the Weapon-Salve (London, 1631), 6; Cabeo, Philosophia magnetica, 305; Mark A. Waddell, Jesuit Science and the End of Nature's Secrets (Farnham: Ashgate, 2015), 45-46, 49. On the "contactus virtualis" within the debate, cf. Robert Fludd, Doctor Fludd's Answer unto M. Foster, or the Sequeesing of Parson Fosters Sponge Ordained by Him for the Wiping Away of the Weapon-Salve (London, 1631), 29-33; Theatrum sympatheticum auctum, 149-51, 16869, 222, 273-80, 375; Fortunio Liceti, De secundo-quaesitis per epistolas a claris viris, ardua, varia, pulchra et nobilia quaeque petentibus: in medicina philosophia, theologia, mathesi et alio quovis eruditionum genere (Udine, 1646), 298.

112 See fol. 336v: "virtutem agentem nullo modo esse qualitatem, sed substantiam incorpoream spiritualem." Cf. LaGalla's De sympathia, fol. 94v, in Allacci xxx.

113 On those examples like "fascinatio," "torpedo," and "remora," cf. Kovach, "Action at a Distance in Duns Scotus," 478; Kovach, "Albert the Great," 187, 204; Kovach, "Action at a Distance in St. Thomas Aquinas," 97, 99; Kovach, "Aquinas Theory of Action at a Distance," 159-6o; Goddu, "William of Ockham's Arguments," 233; Brian P. Copenhaver, "A Tale of Two Fishes: Magical Objects in Natural History from Antiquity Through the Scientific Revolution," Journal of the History of Ideas 52, no. 3 (1991): 373-98; Béatrice Delaurenti, "La fascination et l'action a distance: questions medievales (1230-1370)," Médiévales 50 (2006): 137-54; George Molland, "Roger Bacon and the Hermetic Tradition in Medieval Science," Vivarium 31, no. 1 (1993): 159; Dag Nikolaus Hasse, "Der Sturz des Kamels und die Befleckung des Spiegels: Fernwirkungstheorien in arabischen und lateinischen Kommentaren zu Aristoteles" De insomniis', in $\Sigma \tilde{\omega} \mu \alpha:$ Körperkonzepte und körperliche Existenz in der antiken Philosophie und Literatur, ed. Thomas Buchheim, David Meissner, and Nora Wachsmann, Archiv für Begriffsgeschichte, Sonderheft 13 (Hamburg, 2016), 525-41. For a discussion of the "remora," see also in LaGalla's De sympathia, fol. $53 \mathrm{v}$, 77v, in Allacci XXx, and Gallo, "Il filosofo padulese Giulio Cesare Lagalla," 121.

114 See fol. 282r: "Qualis enim ille est Medicus, qui nullam experientiam habet? Cuius ars omnis in hoc consistit, ut depingat ea in aliis libris picta et ficta? [...] Ubi enim desinit Philosophus, ibi incipit Medicus." 
magnet, but instead collects reports on the 'wonders of nature' from ancient and medieval writings in a hitherto unknown quantity. His animating agenda is clear. Allacci wants to show that there are many phenomena in nature that seem inexplicable, but are not unnatural, certainly not 'superstitious,' magical, or demonic. ${ }^{115}$ From all these examples, he draws the conclusion that the weapon salve must not be condemned either, especially since similar examples of 'actio in distans' can be found in the writings of the most learned and pious men. ${ }^{116}$ The physical working of the weapon salve is therefore not inconsistent, superstitious, diabolical, or magical (neque incongrua, neque superstitiosa, neque diabolica, neque magica). If one does not conceive of the salve in the superstitious concepts of some Paracelsians, then it is not only legitimate, but even serves the public. ${ }^{117}$ LaGalla made a similar effort by trying to cut loose the connection between the salve and Paracelsus's condemned alchemy and medicine, which, according to LaGalla, was rightly prosecuted by the Inquisition and Catholic censorship. ${ }^{118}$

In the third book, Allacci demonstrates that he knows the literature of 'materia medica' very well and, unlike in the previous books, also makes egostatements several times, as does LaGalla. ${ }^{119}$ Allacci seems to depend on his

115 See fol. 350v: "Temerarium quippe est [...] damnare, quod naturae ope fieri potest, eoque magis cum nihil magicum intersit nec implicitum nec explicitum, ut aperius demonstravimus."

116 See fol. 389v: "Ad hec ex probabilibus in Philosophia dogmatibus actio hec indistans confirmatur ardicum namque est, et sane iniquum esset, damnare illud vel explodere tamquam diabolicum et superstitiosum quod tantorum virorum et pientissimorum et scientissimorum testimonio comprobatur."

117 See fol. 417V-418r: "Quare conclude una mecum sodes, curationem magneticam, sive unguentum Armarium quod distans vulnus sanat non appositum vulneri, tantum applicatum teli vel alterius rei cuiuscunque iniunctione, non modo quo Goclenius, Oswaldus, Mylius aliique prestigiatores homines precipiunt, sed alio quopiam legitimo et sincero, quo divinus vir Lagalla, nec non et ipse met conficere consuevimus, nullo modo esse superstitiosum, magicum, et diabolicum, sed mere naturale ab omni prestigio alienum, ideoque non esse eijciendum e consortio hominum. Quin immo maximo Reipublice humane commodo omnes Principes eius usum in suis ditionibus non inferre tantum, sed etiam deberent precipere ne genus humanum in propriam perniciem preceps ob defectum huiusce curationis maioribus afflictum incommodis ad internecionem ruat."

118 See LaGalla's De sympathia, fol. 87v, 91r, 92r, 96r, in Allacci xxx. Cf. esp. ibid. fol. 96r: "De Theophrasto Paracelso nulli dubium est, quod sit auctor damnatus, et haereticus, et suspectus de commercio deaemonis, quare non solum hoc unguentum, sed omnis eius doctrina fugienda est. Haereticum enim homines de vita, ut inquit beatus Paulus Apostolus."

119 He mentions not only well-known authors such as Alexander of Tralles, Thomas Erastus, and Joseph Duchesne, but also lesser known authors such as Ambroise Paré, Petrus van 
teacher's experience as a practicing physician, often referencing LaGalla. ${ }^{120}$ The latter, supporting his claims with anecdotal evidence, even brings to bear a few stories about scholars and Italian noblemen in Rome and Naples, and goes so far as to allude to his childhood and his father Roberto (pater) and his stepfather (patronus) Girolamo LaGalla.'121 Most of this is intended to offer proof of quasi-miraculous cures impossible to explain in the framework of established medicine. However, LaGalla's and Allacci's literature reviews on the weapon salve are particularly interesting because they demonstrate not only knowledge of the ideas of Paracelsus - and, in the case of Allacci, of his successors Oswald Croll and Johann Daniel Mylius-but also of the debate between Rudolph Goclenius, Jean Roberti, and Johann Baptist van Helmont up to $1621 .{ }^{122}$ Allacci even mentions the contribution of Johann Ernst Burggrav. ${ }^{123}$ Some of these books are still in the possession of the Vallicelliana and the Vaticana and, most likely, were those studied by LaGalla and Allacci, who might have even brought some of them to Rome from their travels north of the Alps. ${ }^{124}$ Moreover, both were very aware that Catholics like the Jesuit Roberti-referred to by LaGalla always with the highest esteem as 'pater Roberti' - rejected the weapon salve as work of the devil. ${ }^{125}$ LaGalla clearly labels Goclenius as a

Foreest, and Jacques Houllier. For ego-statements, see fols. 257v, 271v, 282r, 336r; in LaGalla's De sympathia, see fol. 45r, 56v, 78v, 84v, 85r, 9ov, in Allacci xxx.

120 See fols. 307r, 314V, 344r.

121 LaGalla was born in Naples and lost his parents as child and was raised by his father's uncle. LaGalla refers, e.g., to Giovanni Bernardino Longo and probably to Vincenzo Carafa. On Longo and LaGalla, cf. Gallo, "Ancora su Giulio Cesare Lagalla," 168.

122 On the "Unguentum sympatheticum seu stellatum Paracelsi," see Oswald Croll, Basilica chymica: continens philosophicam propria laborum experientia confirmatam descriptionem \& usum remediorum chymicorum selectissimorum è lumine gratiae \& naturae desumptorum (Frankfurt, 16o9), 278-82. Cf. also Johann Daniel Mylius, Opus medico-chymicum, vol. 2 (Frankfurt, 1618), 376-87.

123 Johann Ernst Burggrav, Biolychnium; seu, Lucerna, cum vita ejus, cui accensa est Mystice, vivens jugiter; cum morte ejusdem expirans; omnesque affectus graviores prodens (Franeker, 1611), 129-49.

124 Cf. Rudolph Goclenius, Tractatus novus de magnetica vulnerum curatione (Francofurti: impensis Petri Muscoli, \& Ruperti Pistorij, 1613), shelfmark B.Vall. S.воR Q.III 85 (see also BAV, R.G.Medic. V.401); Jean Roberti, Curationis magneticae, \& unguenti armarii magica impostura (Luxembourg, 1621), shelfmark B.Vall. S.воR Q.III 85; Roberti, Metamorphosis magnetica Calvino-Gocleniana, qua Calvino-dogmatistae (Liège, 1618), shelfmark BAV Stamp.Chig.V.1829(int.2); Roberti, Goclenius heautontimorumenos: id est Curationis magneticae \& unguenti armarii ruina (Luxembourg, 1618), shelfmark BAV R.G.Medic.V.2182; Stamp.Chig.V.1829(int.1); Johann Ernst Burggrav, Biolychnium seu lucerna, cum vita ejus, cui accensa est mysticè, vivesiugiter (Franeker, 1611), shelfmark BAv R.G.Medic.V.28.

125 On Goclenius, Roberti and van Helmont in De sympathia, cf. esp. fols. 86r, 91r-v, in Allacci $\mathrm{xxx}$. 
heretic, but points out that the salve can work without skull ingredients and other heretical procedures or unsound ingredients. ${ }^{126}$ Their own counterarguments, however, are similar to those of van Helmont, an author who was persecuted by the Inquisition at about the same time: the weapon salve works without illicit magic, quite naturally following the model of magnetic phenomena. However, at least Allacci surpasses van Helmont in listing comparisons with other 'wonders of nature.'

That LaGalla and Allacci were able to promote the weapon salve is astonishing, and quite without parallel, considering that LaGalla was a physician to important clerics and Allacci was an employee of the Vatican. This account of De sympathia and De magnete would certainly have stood in the way of publication of both. When Allacci published his posthumous LaGalla biography in 1644, he stated that LaGalla defended the salve against many critics in his De sympathia, grounding it on solid experience. ${ }^{127}$ Yet, Allacci himself did not take a stand in the public arena.

\section{4}

\section{Conclusion}

Though LaGalla's and Allacci's defense of the weapon salve might have been an obstacle to the publication of their works, still to be considered is the question why Allacci composed his enormously lengthy work in the first place. $^{128}$ A sole defense of the salve-which comprises only a third of the work - would have been much less burdensome than an entire anthology on the magnet, including topics irrelevant to the medical issues of book three. Allacci neither discloses his reasons nor offers an original account, new experiments, or any research agenda beyond 'collecting,' which authors at the time conventionally do. It thus may be argued that his main goal was to

126 Cf. esp. fols. 87v, 91r, in Allacci xxx.

127 See Allacci, Vita, 9-10: "De Sympathia et Antipathia rerum, ad defendum unguento, quod vocant Armarium, sive Magneticam curationem, a multis temere oppugnata, et tanquam superstitiosum damnatum. Quod ipse sine ulla superstitione expertus, verum et legitimum esse compererat, et hoc vi, facultateque rerum naturali, quorum nobis virtutes ignotae." See also Gallo, "Il filosofo padulese Giulio Cesare Lagalla," 124, n. 25.

128 LaGalla's reasons to compose his De sympathia are not explicitly expressed, either, but it can be argued that as natural philosopher and physician by profession a critical discussion of the concept of "sympathy and antipathy" requires much less an explanation, especially given the focus on the weapon salve, being a hot issue of the time among physicians and philosophers. 
create an anthology about the conspicuous and highly controversial subject of magnetism. Additionally, he might have been inspired by LaGalla's short discussion of the subject together with the salve. Perhaps after LaGalla's death in 1624, Allacci considered composing De magnete as a way to continue the intellectual heritage of his adored teacher, whose biography he published twenty years after his death. Allacci's original contribution in the field of magnetism, then, was mainly to compare, classify, and criticize already existing accounts, but on an unprecedented scale, making free use of his skills and resources as librarian of what was likely the largest library in the western world.

Equally to the point, Allacci's De magnete corresponds closely to what Gilbert turned against: writing a thick tome in the 'ocean of books,' in which, above all, he copies, fails to describe any experiments he might have performed and thus reports, even perpetuates, much 'false' knowledge about the magnet and its powers. The third book alone demonstrates greater autonomy, an appreciation of experience and a disputative and thus systematic examination of the weapon salve-albeit with heavy reliance on LaGalla's De sympathia. Allacci's signature style in this medical discussion is his emphasis on ancient and theologically-approved authorities along with his skepticism of the human capacity for understanding works of nature. This astonishing defense of the weapon salve-a supposedly demonic cure which was already incriminated by the Inquisition in the 1620 - is particularly important for LaGalla and Allacci's intellectual profiles, and to the historiography of confessionalisation and censorship more broadly. Nevertheless, this original contribution deserves no less research attention than the rest of Allacci's work-not despite of his method, but precisely because of it, which appears reactionary against the background of Gilbert and a more progressive and seemingly modern experimental research agenda. Both approaches express the complexity of conflicting, and sometimes complementary, early modern scholarly trends. Finally, the primary philological approach to physical topics, which figured prominently in the early modern period, also suggests a connection between the disciplines of 'philology' and 'physics,' in the development of specific epistemic modes and patterns. The so-called 'physical reality' is represented here as an intertextual web, which was extended, sorted, or criticized by erudite scholars of the early modern period. ${ }^{129}$ In this web, the librarian,

129 Cf. esp. Lorraine Daston and Glenn W. Most, "History of Science and History of Philologies," Isis 106, no. 2 (2015): 378-9o. 
owing to his role as learned doxographer, possessed the expertise to ponder a vast number of theories and observations based on textual reports, which often served as the background for supposedly progressive and cutting-edge research. 